
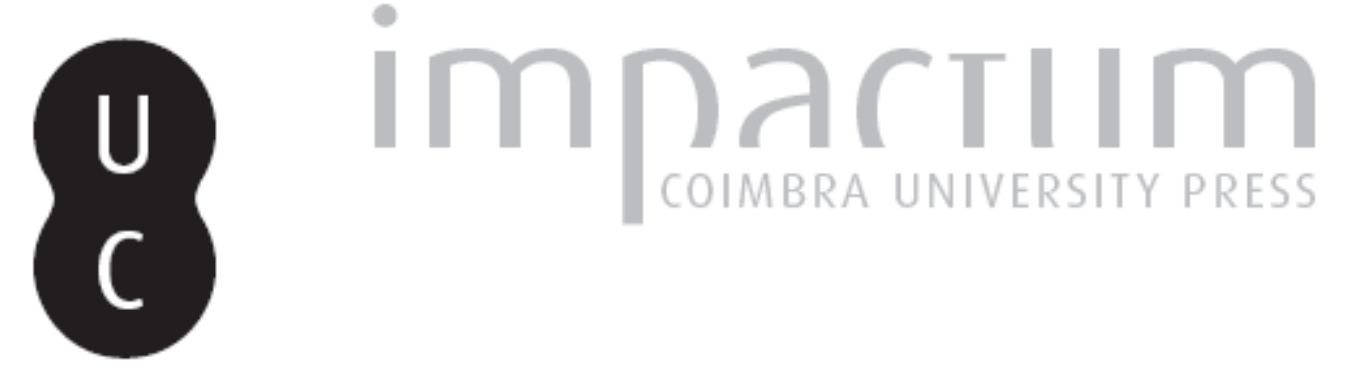

\title{
Repressão de comportamentos femininos numa comunidade de mulheres: uma luta perdida no Recolhimento da Misericórdia de Coimbra (1702-1743)
}

Autor(es): $\quad$ Lopes, Maria Antónia
Publicado por: Instituto de História Económica e Social; Imprensa da Universidade de
Coimbra

URL

persistente:

DOI: $\quad$ DOI:https://doi.org/10.14195/0870-4147_37_8

Accessed : $\quad$ 26-Apr-2023 11:52:12

A navegação consulta e descarregamento dos títulos inseridos nas Bibliotecas Digitais UC Digitalis, UC Pombalina e UC Impactum, pressupõem a aceitação plena e sem reservas dos Termos e Condições de Uso destas Bibliotecas Digitais, disponíveis em https://digitalis.uc.pt/pt-pt/termos.

Conforme exposto nos referidos Termos e Condições de Uso, o descarregamento de títulos de acesso restrito requer uma licença válida de autorização devendo o utilizador aceder ao(s) documento(s) a partir de um endereço de IP da instituição detentora da supramencionada licença.

Ao utilizador é apenas permitido o descarregamento para uso pessoal, pelo que o emprego do(s) título(s) descarregado(s) para outro fim, designadamente comercial, carece de autorização do respetivo autor ou editor da obra.

Na medida em que todas as obras da UC Digitalis se encontram protegidas pelo Código do Direito de Autor e Direitos Conexos e demais legislação aplicável, toda a cópia, parcial ou total, deste documento, nos casos em que é legalmente admitida, deverá conter ou fazer-se acompanhar por este aviso. 


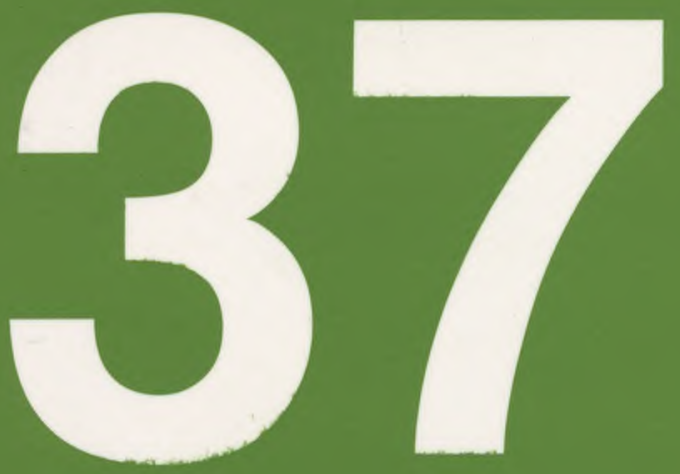

Revista Portuguesa de História

Faculdade de Letras da Universidade de Coimbra Instituto de Historia Econónica e Samial

Coimbra 05 
Revista Portuguesa de Historia

t. XXXVII (2005)

pp. 189-229

\title{
Repressão de comportamentos femininos \\ numa comunidade de mulheres - uma luta perdida no \\ Recolhimento da Misericórdia de Coimbra (1702-1743)
}

\author{
MARia ANTónia Lopes \\ Faculdade de Letras da Universidade de Coimbra \\ Centro de História da Sociedade e da Cultura
}

Numa casa que pela rua de Coruche prolonga a Santa Casa da Misericórdia de Coimbra, vivem, nas primeiras décadas do século XVIII, vinte e poucas mulheres de diferentes idades. As portas mantêm-se fechadas, as janelas cingidas por rótulas. As orações são feitas na penumbra do coro alto que, inserido na igreja da Misericórdia, permanece discreto aos olhares do povo. A entrada de géneros faz-se pela roda para que a porta se não abra. As conversas autorizadas são ouvidas pelas "escutas" que verificam também o trajo das recolhidas, biocos de cores honestas que devem cobri-las da cabeça aos pés. As jovens e adultas moradoras no recolhimento lá envelhecem, aborrecem-se, murmuram, intrigam, gritam, amam-se, insultam-se e agridem-se num espaço demasiado restrito para conter os ânimos e os corpos confinados.

Os homens que no exterior comandam os destinos destas mulheres não se contentam em fechá-las e excluí-las do mundo. Decretam-lhes um quotidiano sombrio, de gestos e palavras contidos, pontuado pelo trabalho, o silêncio e a oração. Por isso há que controlar o que se passa lá dentro, vigiar a aplicação das normas, reprimir e castigar os desvios. São encerradas no recolhimento, mas nem por isso se tornam invisíveis ao olhar dos dirigentes. Como tão insistentemente salientou Michel Foucault, o controlo exerce-se 
mesmo na ausência de quem domina ${ }^{1}$. As devassas que irei analisar obedecem a esse objectivo.

Mas como impedi-las de cantar, bailar, jogar, usar brincos e fitas, acenar das janelas, escrever e namorar? Ano após ano as mulheres, jovens na maioria, plenas de vitalidade, violam as regras. A natureza irrompe sempre. Confundida com perversidade - que assusta e atrai -, a intimidade das recolhidas é devassada pelos visitadores em interrogatórios individuais, secretos e impertinentes e as denúncias registadas no Livro das Visitas do Recolhimento" 2, o único "livro de segredo" que chegou até nós ${ }^{3}$.

Em 1718, D. Ana, jovem de 19 anos, troca cartas e presentes com Manuel Ferreira, rapaz de Coimbra que se diz ir para frade e que, sob o pretexto de visitar a irmã recolhida, frequenta a portaria da casa. D. Ana e a sua amiga Francisca Josefa, de 22 anos, têm por costumes jogar às cartas no coro da igreja, subvertendo completamente um espaço e horário destinados a penitência. Com espírito prático e inventivo, acalmam a consciência substituindo o jogo a dinheiro ou a feijões pelo jogo a Avé-Marias para as almas. Cansadas do jogo, e se as rezas prosseguem, não se inibem de dormir um pouco ou conversar. Francisca Josefa tomou-se de amores por Teresa Caetana. A "amizade ilícita" escandaliza as colegas, mas vem de longe. Em 1714 já haviam sido denunciadas, mas, nessa altura, Francisca Josefa oscilava entre Teresa Caetana e Joana Teresa, a quem preferia. Decidiram os visitadores, em 18 de Junho desse ano, que Francisca Josefa e Joana Teresa fossem admoestadas pelo provedor e castigadas pela regente. Pouco depois Joana saiu para casar e Francisca Josefa reata a "amizade" com Teresa Caetana. No ano seguinte apareceu no recolhimento um "pasquim"4

1 Nomeadamente em Surveiller et punir. Naissance de la prison, Paris, Gallimard, 1993 (Ia ed.: 1975).

2 Arquivo da Misericórdia de Coimbra (doravante: AMC), Livro das Visitas do Recolhimento ( 1702-1743). Estas fontes são raras. Concha Torres Sánchez lamenta não terem sido conservados os livros de visitas anuais dos conventos que estudou e que tanto poderiam esclarecer-nos sobre as infracções cometidas pelas freirás e correcções aplicadas pelos visitadores \{La clausura femenina en la Salamanca del siglo XVII. Dominicas y Carmelitas Descalzas, Salamanca, Universidade, 1991, p. 175).

3 Terá existido pelo menos um outro com os termos das devassas feitas aos capelães, o que se depreende do acórdão de 26.6.1740 para que se façam "huns almarios de gavettas com duas chaves da quais tera huma o Senhor Provedor e outra o Senhor escrivaõ em que se guardem os Livros das Vezittas da Capella e Recolhimento e os mais papeis que ouver de segredo" (AMC, Acordãos 4, fl. 192 ${ }^{\circ}$ ).

4 "Sátira por escrito pregada nas ruas, ou nas portas", Antonio de Moraes Silva, Diccionario da Lingua Portugueza..., Lisboa, Typ. Lacerdina, 1813, 2ª ed., vol. II, p. 406. 
denunciador da situação, o qual, lido em voz alta, valeu à leitora atrevida “desconpusissoens e arranhadelas". Por resolução de 4 de Dezembro, os visitadores decidem punir D. Teresa com prisão rigorosa porque se provara que mantinha correspondência com um vizinho acenando da janela e rótula e que "intentara 1er hum Pasquim feito a orpha Teresa Cahetana e se prezume que a mesma D. Thereza foi Autora delle e que na sua prezença o lera dando motivo a desconpusissoens de palavras que passaraõ a violencias de mãos"5. Quanto a Francisca e Teresa, posto que "contrahiraõ amisade particular a qual se conjectura por muntas testemunhas ser pretérita e se comprova pello juramento da Madre Regente depondo que essa amisade estava quieta pella sua vigilancia e castigo"6, mandam que fiquem sob observação. Mas Francisca Josefa não toma emenda. Em Dezembro de 1716 encontra-se entre as seis recolhidas que escandalizam pelas suas ilícitas amizades. Em 1718, como se viu, suspeita-se, mais uma vez, das relações que mantém com Teresa Caetana.

Eis todo um ambiente de desvio e subversão! Eis como o estereótipo da mulher recolhida, submissa, quieta e piedosa se estilhaça! Em seu lugar aparece a rebeldia, a sensualidade, mas também a auto-repressão e a violência sob múltiplas formas e graus, violência sobre as mulheres, violência entre mulheres ${ }^{7}$.

Se o tema dos amores sáficos, esse vazio historiográfico ${ }^{8}$, é o que mais chama a atenção, não é, contudo, o "crime" mais comum, ou melhor, não o é em todas as idades e condições. Passemos, pois, a uma análise sistemática perdendo, porventura, em poder evocativo mas ganhando em solidez. Antes disso, porém, há que enquadrar a instituição ${ }^{9}$.

5 AMC, Livro das Visitas do Recolhimento, fl. $73 \mathrm{v}^{\circ}$.

6 Idem, ibidem, fl. 74.

7 Veja-se para esta temática, em Portugal, Irene Vaquinhas, Mulheres que se injuriam, mulheres que se batem: alguns valores femininos vistos através de uma análise da delinquência em Coimbra (1850-1915) em A Mulher na sociedade portuguesa. Actas do Colóquio, vol. II, Coimbra, Instituto de História Económica e Social, FLUC, 1986, pp. 307-323 e Violência, justiça e sociedade rural: os campos de Coimbra, Montemor-o-Velho e Penacova de 1858 a 1918, Porto, Edições Afrontamento, 1996. Uma síntese das reflexões epistemológicas que têm sido produzidas sobre a questão e dos resultados da investigação histórica, pode ler-se em Aurízia Anica, As mulheres, a violência e a justiça no Algarve de Oitocentos, Lisboa, Colibri, 2005, pp. 19-61.

8 Ver Marie-Jo Bonnet, Les relations amoureuses entre les femmes, Paris, Editions Odile Jacob, 1995. Para Portugal, consulte-se Paulo Drumond Braga, "Dois casos de homossexualidade feminina no Portugal quinhentista", Vértice, Lisboa, II série, n. ${ }^{\circ}$ 72,1996, pp. 87-90 e, do mesmo autor, A Inquisição nos Açores, Ponta Delgada, Instituto Cultural, 1997, pp. 454-456 e 473-474.

9 Para esse enquadramento, retomo parcelarmente o meu texto sobre os dois recolhimentos de Coimbra \{Pobreza, assistência e controlo social em Coimbra (1750-1850), Viseu, Palimage, 2000, vol. I, pp. 429-433,485-491). 
Os recolhimentos foram um dos mecanismos de controlo dos destinos mulheris utilizados pelas autoridades eclesiásticas, civis e familiares, no intuito de combater aquilo que consideravam marginalização social feminina, sinónimo de degradação moral, isto é, liberdade sexual ${ }^{10}$. Foi uma das estratégias que com mais eficácia alcançou o obj ectivo da normalização, impedindo o desvio social com o internamento das crianças e mulheres jovens, ou castigando-o com o recolhimento das que

10 São vulgares nos séculos XVI a XIX e com antecedentes em épocas anteriores. Ver JeanPierre Gutton, La société et les pauvres. L 'exemple de la généralité de Lyon, 1534-1789, Paris, "Les Belles Lettres", 1971, pp. 389-393; María Dolores Pérez Baltasar, "Orígenes de los recogimientos de mujeres", Cuadernos de Historia Moderna y Contemporánea, Madrid, Universidad Complutense, Facultad de Geografía e Historia, vol. VI, 1985; Stuart Woolf, Los pobres en la Europa Moderna, Barcelona, Editorial Crítica, 1989, pp. 39-41; Sandra Cavallo, Charity and power in early modem Italy. Benefactors and their motives in Turin, 1541-1789, Cambridge, Cambridge University Press, 1995, pp. 156-167; Para Portugal, veja-se D. Antonio da Costa, Historia da instrucção popular em Portugal desde a fundação da monarchia até aos nossos dias, Lisboa, Imprensa Nacional, 1871, pp. 181-188; Victor Ribeiro, Historia da beneficencia publica em Portugal, Coimbra, Imprensa da Universidade, 1907, cap. VIII; Victor Ribeiro, A Santa Casa da Misericordia de Lisboa (subsídiospara a sua história) 1498-1898, pp. 429-440; Ângelo Ribeiro, "Assistência" in História de Portugal, Barcelos, Portucalense Editora, 1933-1935, vol. V, pp. 466-469 e vol. VI, pp. 632-634; Maria Amélia Lemos Alves e Fernando Jasmins Pereira, "Recolhimentos" in Dicionário de História da Igreja em Portugal, dir. de A. A. Banha de Andrade, vol. I, Lisboa, Editorial Resistência, 1980, pp. 675-676; Maria de Fátima Castro, O Recolhimento das Beatas de Santo António do Campo da Vinha. Da sua instituição à administração pela Santa Casa da Misericórdia, sep. de Bracara Augusta, Braga, Câmara Municipal de Braga, vol. 46, 1995/96; Maria Marta Araújo, Pobres, honradas e virtuosas: os dotes de D. Francisco e a Misericórdia de Ponte de Lima (1680-1850), Ponte de Lima, Santa Casa da Misericórdia, 2000, pp. 17-42; Maria de Fátima Reis, "Poder régio e tutela episcopal nas instituições de assistência na época moderna. Os Recolhimentos de Lisboa” em Igreja, caridade e assistência na península ibérica (sécs. XVI-XVIII), ed. de Laurinda Abreu, Lisboa, Colibri/CIDEHUS-UE, 2004, pp. 263-274; Marco Liberato, "Trento, a mulher e o controlo social", idem, pp. 275-289. Sobre alguns recolhimentos nos territórios coloniais portugueses ver Timothy J. Coates, Degredados e Órfãs: Colonização dirigida pela Coroa no Império Português, 1550-1755, CNCD, 1998, pp. 205-213,217-220,225-256; Maria de Jesus dos Mártires Lopes, "As recolhidas de Goa em setecentos" em O rosto feminino da expansão portuguesa, Actas do congresso internacional (1994), vol. I, Lisboa, Comissão para a Igualdade e para os Direitos das Mulheres, 1995, pp. 653-664; Ana Isabel Marques Guedes, "Tentativas de controle da reprodução da população colonial: as órfas d'el-rei", Idem, pp. 665-673; Maria Filomena Valente Belo, "Os recolhimentos femininos e a expansão (séculos XVI-XVII), Ibidem, pp. 675-685; Leila Mezan Algranti, “À sombra dos círios: o cotidiano das mulheres reclusas no Brasil colonial”, Ibidem, vol. II, pp. 467-476; Isabel dos Guimarães Sá, Quando o rico se faz pobre: misericórdias, caridade e poder no Império português, 1500-1800, Lisboa, Comissão Nacional para as Comemorações dos Descobrimentos Portugueses, 1997, pp. 197-204; Leila Mezan Algranti, Livros de devoção, atos de censura. Ensaios de história do livro e da leitura na América Portuguesa (1750-1821, São Paulo, Hucitec, 2004, pp. 23-51. 
optavam ou involuntariamente caíam em situações socialmente reprováveis". Saliento que o conceito de estima social e seus derivados semânticos remetem - sem dúvida de forma redutora porque outras valorações existiam, nomeadamente nos meios que tais representações consideravam marginais - para uma noção de consenso ao nível das elites formadoras, consenso esse que, quanto ao comportamento sexual feminino, sem dúvida existe. Segundo as concepções do tempo, a família era o amparo natural e necessário das mulheres, mas quando o escudo familiar se fragilizava pela morte ou ausência do pai ou pela degradação económica do agregado, o recolhimento oferecia um bom sucedâneo: a mulher recolhida era impedida de prevaricar pela estrita reclusão, aí assimilava os valores e ensinamentos adequados ao seu sexo, podendo depois pelo casamento, por emprego doméstico ou pela entrega a parente responsável, regressar, agora correctamente enquadrada, ao seio da sociedade.

Existiam em Coimbra, durante o período em apreço, dois recolhimentos de mulheres: o Recolhimento do Paço do Conde e o Recolhimento da Misericórdia. $\mathrm{O}$ primeiro destinava-se, em princípio, a mulheres adultas com um passado reprovável que aí se iam regenerar, e o segundo estava vocacionado para receber órfãs jovens, mas, desde 1709, acolheu também porcionistas, mulheres isoladas, de parcos recursos e honestos costumes, facultando-lhes o alojamento gratuito. Elas próprias, pelo produto do seu trabalho ou com a ajuda de protectores, pagavam o sustento e outras necessidades quotidianas e pelo facto de viverem recolhidas valorizavam-se socialmente, numa ilusória aparência de abastança e ociosidade por não procurarem o sustento no serviço de casa alheia ou nas vendagens de rua. Aí escondiam uma pobreza envergonhada mantendo a sua honra e a da família, pois para estas mulheres estava vedada a profissão religiosa pelos elevados valores que atingiam os dotes exigidos às freiras ${ }^{11} 12$.

${ }^{11}$ Remete-se para Arlette Farge e Michel Foucault, Le désordre des familles: lettres de cachet des archives de la Bastille (Paris, Gallimard-Julliard, 1982) e para Catharina Lis e Hugo Soly, Disordered Lives. Eighteenth-Century Families and their unruly relatives (Cambridge, Polity Press, 1996). As obras não se cingem ao depósito de mulheres às ordens dos pais ou maridos, mas englobam todas as reclusões compulsivas dos indesejáveis (loucos, rebeldes, ociosos, dissipadores...) a requerimento de familiares que podiam ser também mães ou esposas.

${ }^{12}$ Em 1659 foi ordenado à abadessa do convento de St. ${ }^{a}$ Clara de Vila do Conde que "não receba para freirás senão mulheres fidalgas, filhas de homens fidalgos e senhores de terras; e o dote destas será de mil crusados, e as mulheres filhas de homens de habito de Christo ou Santiago por quinhentos mil réis" (ordem dada pelo provincial e citada por T. Lino d'Assumpção em As ultimas freirás..., Porto, Livraria Portuense de Lopes \& Ca, 1894, p. 91). Entre 1730 e 1780 o valor dos dotes das religiosas admitidas no Mosteiro de Santa Clara do Porto oscilou entre um milhão e um milhão e duzentos mil réis (Maria Eugénia Matos Femandes, O mosteiro de Santa Clara do Porto em meados do séc. XVIII (1730-80), Porto, Arquivo Histórico/Câmara Municipal, 1992, p. 58). Num mosteiro 
O Recolhimento das Órfãs da Misericórdia de Coimbra foi inaugurado em 8 de Dezembro de 1701 em cumprimento do legado de Manuel Soares de Oliveira, natural da vila de Pereira e falecido em 3 de Novembro de 1675 na cidade de Manila, onde era assessor e auditor geral do governador geral das ilhas Filipinas. Pelo seu testamento de 30 de Novembro de 1674 deixou uma avultadíssima herança destinada, em boa parte, à Misericórdia de Coimbra, impondo-lhe várias obrigações, entre elas a abertura de um recolhimento ou colégio de órfãs que seria organizado à semelhança do Recolhimento da Misericórdia de Lisboa. Abriu o de Coimbra com uma regente, uma porteira, duas criadas de dentro, uma de fora e apenas duas órfãs. Três meses depois foram admitidas mais quatro órfãs. Segundo as normas instituídas, as órfãs (de pai ou de pai e mãe) seriam obrigatoriamente pobres, com idades compreendidas entre 14 e 20 anos e permaneceriam no recolhimento durante quatro anos, findos os quais, sairiam para dar lugar a outra. A instituição tinha como principal objectivo a clausura e preparação de raparigas para o casamento, recolhendo-as em idade perigosa, impedindo-as de se perderem no pecado (destino considerado provável das mulheres moças desamparadas de pai e de fortuna), prepará-las para boas mães de família com a aprendizagem de tarefas domésticas e uma rudimentar instrução moral e religiosa e procurar-lhes marido conveniente oferecendo-lhes um dote importante. Se as órfãs casassem durante o tempo de permanência no recolhimento, o que só poderiam fazer com licença da Mesa, a Santa Casa entregava-lhes o dote de 80.000 réis. Se não conseguissem casar no prazo estabelecido tinham de sair, mas levavam consigo a carta de dote com validade por um ano, findo o qual, não casando, ficava devoluto. O noivo era inquirido e sujeito à aprovação da Misericórdia e o casamento realizava-se na igreja da Santa Casa, saindo a órfã do recolhimento já casada para ser entregue ao seu marido. Era este que depois vinha receber o dote.

Nenhuma das recolhidas podia falar com pessoa alguma, excepto pai, mãe, filhos e irmãos sempre com autorização da regente. Nenhum irmão da irmandade poderia entrar no recolhimento, salvo com causa urgente, licença da Mesa e obrigatoriamente acompanhado por um confrade e pelo escrivão. Era também necessária a autorização dos mesários para a entrada de médico, cirurgião ou barbeiro. Todos os meses seriam chamados os confessores. Até 1715 era a regente que distribuía por todas os alimentos necessários, mas porque o sistema gerava conflitos, queixando-se as órfãs de parcialidade e injustiça na distribuição dos 
víveres, a Mesa da Misericórdia, por termo de 1.7.1715, decidiu atribuir a cada uma das órfãs e oficiais um ordenado, ficando assim instituídas as seguintes mesadas: 4.000 réis à regente, 3.000 à porteira e 2.000 a cada órfã ${ }^{13}$. A regente competia o governo económico e administrativo do recolhimento e exigia-se-lhe não só capacidade para dirigir a casa, mas também para vigiar e educar as recolhidas, como compete a uma boa mãe. À porteira recomendava-se toda a prudência pois, como se escreve em 1774, "na Guarda da familia delle [recolhimento] conciste a honra decorosa da sua exiztencia"14. Em 1728 foi criado o lugar de mestra, a quem se encarregou a educação das órfãs ${ }^{15}$, mas como o Livro das Visitas apresenta um hiato entre Dezembro de 1727 e Junho de 1740, essa categoria só surge nas inquirições deste último ano. Eram estas, em síntese, as normas que presidiam ao funcionamento da instituição.

No livro de visitas aqui explorado ${ }^{16}$ foram exaradas vinte devassas, interrogatórios individuais conduzidos pelo provedor e que se prolongavam por vários dias. A primeira visita efectuou-se logo em Abril de 1702, quatro meses após a abertura da instituição. Viviam nessa altura no recolhimento cinco órfãs, além das duas preladas e das criadas, que não foram inquiridas. Ainda no mesmo ano, em Dezembro, foi feita a segunda devassa, as quais continuaram com regularidade até Agosto de 1723, data da 17a. Há a seguir uma interrupção até Dezembro de 1727 e, depois, um longo silêncio entre essa data e Junho de 1740. Em 1743 regista-se o último interrogatório geral.

Menos de uma dezena até 1709, ano em que atingem o número de 11, as mulheres

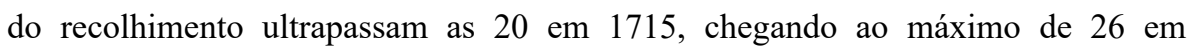
1718 e 1727 e de 27 em 1743. A "Oficialidade" ou "Preladas" eram, como disse, uma regente e uma porteira, a que se juntou uma mestra em 1728. Em 1718

13 AMC, Acordaos $4^{\circ}$, fl. 95-95v ${ }^{\circ}$. As mesadas estabelecidas em 1715 mantiveram-se inalteráveis até 1800 .

14 AMC, Acordãos 50, fl. 24.

${ }^{15}$ AMC, Acordãos $4^{\circ}$, fl. $142 v^{\circ}$.

16 Embora se intitule Livro das Visitas do Recolhimento, é na realidade um livro de devassas gerais porque nele se transcrevem as informações colhidas nos interrogatórios feitos a todas as recolhidas e nunca os resultados de uma inspeç̧ão à casa que tudo indica não ser realizada. Sobre os processos, resultados, significado e importância enquanto fonte histórica das visitas pastorais, ver Joaquim Ramos de Carvalho, As visitas pastorais e a sociedade de Antigo Regime: notas para o estudo de um mecanismo de normalização social, Coimbra, 1985, policopiado e A jurisdição episcopal sobre leigos em matéria de pecados públicos: as visitas pastorais e o comportamento moral das populações portuguesas de antigo regime, Coimbra, 1990, sep. da Revista Portuguesa de História, 24; José Pedro Paiva, Inquisição e visitas pastorais: dois mecanismos complementares de controle social?, Coimbra, 1989, sep. da Revista de História das Ideias, 11. 
vivia também na instituição uma porteira aposentada. Depois de 1713 foram também interrogadas as criadas, que eram duas até 1727, ano em que passou a haver três de dentro e uma de fora. As órfãs oscilaram entre o mínimo de três em 1705 e 1713 e o máximo de 11 em 1743 e 10 em 1718 e 1727 . Quanto àsporcionistas, que surgem em 1709 (apenas duas), constituirão em vários anos a categoria mais populosa do recolhimento, com o máximo de 14 em 1715, sendo então as órfãs apenas cinco. Embora só cerca de um terço das interrogadas declare a idade, os registos apontam para uma média de 28 anos, idade que, naturalmente, difere segundo a categoria. Assim, as regentes têm em média 55 anos, as porteiras 48, a mestra 42, as criadas 38, as porcionistas 25 e as órfãs 20 . As porcionistas, que não estavam sujeitas a constrangimentos etários, apresentam a maior variação, indo dos 13 aos 60 anos. No conjunto, 51\% das recolhidas situavam-se entre os 18 e os 27 anos. População jovem, portanto.

É possível caracterizá-las quanto à estima social de que gozavam e quanto à sua literacia. Eram pobres, em princípio, mas tal não significa que não fossem respeitadas enquanto membros de famílias socialmente categorizadas. $\mathrm{O}$ tratamento de dona, marca de distinção social, não deixa margem para dúvidas. Ora, 30\% das recolhidas eram assim tratadas. Estamos, pois, em boa parte, face a uma pobreza envergonhada muito selecta, não a pobreza envergonhada ou meritória fornecida pelo mundo do artesanato honrado, mas sim perante gente "principal". Quase metade das inquiridas sabe assinar - o que é invulgar num universo feminino -, salientando-se as preladas (59\%) e as porcionistas (56\%). Amaioria das órfãs $(69 \%)$ não o sabe fazer nem, evidentemente, as criadas, embora um tanto surpreendentemente uma delas assine o seu nome. $\mathrm{O}$ facto de pertencerem a famílias respeitadas, o que lhes confere o tratamento de "dona", não significa que a instrução literária tenha sido mais cuidada. Entre estas, sabem assinar $42 \%$ e no universo das restantes, incluindo as criadas, sabem-no 45\%. De notar, também, que várias recolhidas aprendem a assinar durante a estada no recolhimento e que na década de 1740 a iliteracia é superior à dos anos vinte, respectivamente de 60 e 50\%.

Começando pela abordagem mais simples, a contagem de denunciantes por épocas, deparamo-nos com resultados que apontam para um quotidiano tenso, revelador de muitas e profundas frustrações. Os anos Vinte e Quarenta, com níveis muito elevados de acusações, são os períodos de maior crispação. Em 1740 e 1743, 90\% dos depoimentos são acusadores e entre 1721 e 1727 atingem os 92\%. Em contrapartida, durante os primeiros anos do recolhimento, o ambiente foi pacífico, com dois terços das recolhidas a manifestar ausência de quaisquer queixas. $\mathrm{O}$ que não revela que as normas importas pela Mesa da Misericórdia fossem cumpridas. Se as mulheres se mantivessem unidas, recusando-se a pactuar com os dirigentes e a exercer a auto-repressão, era fácil ocultar os desvios aos inquiridores. 
Quadro 1 - Depoimentos acusatórios e não acusatórios por épocas

\begin{tabular}{|c|c|c|c|}
\hline Épocas & $\begin{array}{c}\text { Depoimentos } \\
\text { acusatórios }\end{array}$ & $\begin{array}{c}\text { Depoimentos não } \\
\text { acusatórios }\end{array}$ & $\begin{array}{c}\text { Total de } \\
\text { depoimentos }\end{array}$ \\
\hline $1702-09$ & 15 & 31 & 46 \\
\hline $1710-18$ & 117 & 43 & 160 \\
\hline $1721-27$ & 55 & 5 & 60 \\
\hline $1740-43$ & 45 & 5 & 50 \\
\hline Total & 232 & 84 & 316 \\
\hline
\end{tabular}

Quadro 2 - Depoimentos acusatórios e não acusatórios por categorias

\begin{tabular}{|c|c|c|c|}
\hline Categorias & $\begin{array}{c}\text { Depoimentos } \\
\text { acusatórios }\end{array}$ & $\begin{array}{c}\text { Depoimentos não } \\
\text { acusatórios }\end{array}$ & $\begin{array}{c}\text { Total de } \\
\text { depoimentos }\end{array}$ \\
\hline Regente & 16 & 4 & 20 \\
\hline Porteiras & 16 & 6 & 22 \\
\hline Mestra & 2 & & 2 \\
\hline Órfãs & 86 & 44 & 130 \\
\hline Porcionistas & 93 & 28 & 121 \\
\hline Criadas & 19 & 2 & 21 \\
\hline Total & 232 & 84 & 316 \\
\hline
\end{tabular}

Analisando o quadro 3 e deixando de lado a mestra, presente apenas em duas devassas (de 1740 e 1743), as mais delatoras são as criadas, denunciando as recolhidas em 90\% dos seus depoimentos. A vigilância exerce-se aqui de baixo para cima, num momento único e não desperdiçado de inversão das relações de poder. A situação da regente é ingrata quando se inquire sobre o quotidiano da casa. Se não denuncia, será suspeitade autoria, conivência ou encobrimento das irregularidades que as inquiridas ouvidas depois dela irão, por certo, revelar; se acusa em demasia, demonstra incompetência. Apesar deste risco, a partir de 1710, opta por denunciar sempre alguma coisa. Veremos adiante que delitos revela e que tipo de recolhidas acusa. Vêm a seguir as porcionistas, denunciantes em $77 \%$ dos casos. As órfãs, talvez pela sua juventude e porque permanecem menos tempo no recolhimento, são as mais indulgentes ou menos insatisfeitas. Mas isso só acontece nos primeiros anos em análise, pois a partir de 1721 serão muito mais críticas do que as porcionistas e na década de 1740 ainda mais do que as criadas, comportamento que perceberemos quando se analisarem as suas razões de queixa. Se procurarmos a sanha persecutória por nível social, verificamos que as donas são mais indulgentes (31\%) do que as outras $(25 \%)$. 
Quadro 3 - Percentagem de denunciantes por época e por categoria

\begin{tabular}{|c|c|c|c|c|c|c|c|}
\hline Épocas & Órfãs & Porcionistas & Porteira & Regente & Criadas & Mestra & Total \\
\hline $1702-09$ & 28,1 & 50,0 & 50,0 & 33,3 & & & 32,6 \\
\hline $1710-18$ & 62,3 & 75,3 & 72,7 & 100,0 & 90,0 & & 73,1 \\
\hline $1721-27$ & 100,0 & 78,3 & 100,0 & 100,0 & 100,0 & & 91,7 \\
\hline $1740-43$ & 94,7 & 84,2 & 100,0 & 100,0 & 83,3 & 100,0 & 90,0 \\
\hline Total & 66,2 & 76,9 & 72,7 & 80,0 & 90,5 & 100,0 & 73,4 \\
\hline
\end{tabular}

Regente e criadas foram alvo de acusações de 37\% dos depoimentos acusatórios (excluindo os delas próprios). A porteira, visada em $39 \%$ é um pouco mais denunciada. O grosso das queixas refere-se, naturalmente, pelo seu peso numérico, às órfãs, com $64 \%$ das recolhidas queixosas a visarem-nas, e, principalmente, às porcionistas, com $75 \%$. Nos anos Quarenta as relações com a regente estão muito degradadas, época em que crescem as queixas das órfãs e melhora o relacionamento geral com a porteira. Com esta, a crispação foi muito grande na década de 1720, como se pode perceber pela análise dos quadros seguintes.

Quadro 4 - Recolhidas denunciadas por épocas - \% de depoimentos acusatórios

\begin{tabular}{|c|c|c|c|c|c|c|}
\hline Épocas & Regente & Porteira & Mestra & Criadas & Órfãs & Porcionistas \\
\hline $1702-09$ & 38,5 & 0 & & 40 & 6,7 & 46,7 \\
\hline $1710-18$ & 13,9 & 24,8 & & 9,4 & 80,3 & 94 \\
\hline $1721-27$ & 59,6 & 80,8 & & 50,9 & 69,1 & 69,1 \\
\hline $1740-43$ & 67,4 & 34,9 & 43 & 91,1 & 31, & 42,2 \\
\hline
\end{tabular}

Quadro 5 - Denunciantes e denunciadas - \% de depoimentos acusatórios

\begin{tabular}{|c|c|c|c|c|c|c|}
\hline Denunciantes & Regente & Porteira & Mestra & Criadas & Órfãs & Porcionistas \\
\hline Criadas & 26,3 & 42,1 & 80 & 26,3 & 63,2 & 63,4 \\
\hline Mestra & 100 & 50 & & 100 & & \\
\hline Orias & 44,2 & 40,7 & 94,4 & 46,5 & 59,3 & 79,1 \\
\hline Porcionistas & 30,1 & 36,6 & 31,3 & 31,2 & 66,7 & 75,3 \\
\hline Porteira & 43,8 & & 100 & 50 & 50 & 62,5 \\
\hline Regente & & 37,5 & 100 & 12,5 & 87,5 & 87,5 \\
\hline
\end{tabular}

Presente apenas em 1740 e 1743 - e à excepção das porcionistas que não tinham obrigatoriamente de se relacionar com ela-, a mestra foi um elemento que concitou o desagrado geral. Por sua vez, ela própria acusa mais do que as outras educadoras, revelando-se com esta mulher uma incompatibilidade quase total. Veremos adiante 
que os motivos decorrem da sua incompetência e não se prendem com conflitos de poder entre as dirigentes. A insatisfação relativamente às criadas é também grande, muito especialmente na década de 1740. Mas também não colhem a aprovação de mais de metade das mulheres do recolhimento nos anos Vinte. Só entre 1710e 1718 agradaram, de facto, às recolhidas. Ressalta o melhor relacionamento das criadas com a regente, cumplicidade que não existe com a porteira, com quem mantêm relações tensas inteiramente correspondidas. Entre a regente e a porteira houve, de facto, graves conflitos na década de Vinte que provocaram o nascimento de facções entre a população do recolhimento e o avolumar das queixas contra as preladas e, sobretudo, contra a porteira. As acusações feitas às órfãs vêm da regente. A porteira é a que menos tem a dizer delas. $\mathrm{E} o$ mesmo se passa relativamente às porcionistas, embora o comportamento destas colida um pouco mais com os deveres da guardiã da porta.

Vejam-se agora as razões de queixa e os desvios apontados. Aprincipal acusação feita à regente é a de frouxidão, permitindo violações do regulamento - frouxidão em geral, por vezes sem concretização, mas também pormenorizadas, como quando a acusam de consentir visitas proibidas, inimizades (que por vezes degeneram em bulhas) e o uso de roupas e/ou adereços vedados pelo regimento. Mas o que menos se lhe perdoa é o facto de consentir incumprimentos ou atrevimentos às criadas. Em 1740 e 1743 as acusações tomam-se mais graves, sendo denunciada por manter amizade escandalosa com uma das criadas. Em média, cada delatora da regente (80 no total), aponta à prelada duas irregularidades. Mais contestada é a porteira. Acusam-na 84 recolhidas, com três "delitos" em média e mais graves do que os da regente. Não lhe perdoam o incumprimento dos deveres do seu ofício, nomeadamente faltar às orações, permitir visitas proibidas e correspondência com homens. A segunda grande censura é a de parcialidade no tratamento das recolhidas ou mesmo o fomento de inimizades. Que é áspera, podendo atingir a grosseria, e inimiga de várias, incluindo a regente, são outras acusações graves de que é alvo. Só duas vezes é apontada por frouxidão e uma por se cartear com um homem. Quanto à mestra, era, claramente, incompetente. Pouco ou nada ensina porque não sabe mais do que as outras, dizem-no $28 \mathrm{em} 30$ testemunhas. Além disso, fomenta inimizades "por falar e aumentar", não sabe 1er nem escrever, tem maus modos e "falta de juízo", o que, para algumas, explica o seu comportamento impróprio.

As criadas são duramente criticadas sobretudo pela falta de respeito para com as órfãs e porcionistas ou mesmo preladas, incumprimento de obrigações e grosseria e agressividade. Além disso, mas em menor grau, há quem não lhes perdoe adomarem-se de forma proibida, comunicarem com o exterior, chegando a revelar os "podres" do recolhimento, servirem de correio secreto levando e 
trazendo cartas, e ainda, relativamente a uma delas nos anos Quarenta, como já disse, de manter amizade ilícita com a regente. Em média, cada denunciante aponta às criadas 2,3 infracções.

A acusação mais frequente feita às órfãs é a de comportamento impróprio na igreja ou no recolhimento em geral. As inimizades mantidas e fomentadas - e que com alguma frequência desembocavam em injúrias e pelejas - são o segundo motivo de censuras. Vem logo a seguir, com 53 denúncias (18\% do total de acusações feitas às órfãs), a prática ou suspeita de homossexualidade com as designações de "amizade escandalosa" ou "amizade ilícita". Estas expressões talvez nem sempre significassem que se acreditava em homossexualidade praticada, mas que tais preferências eram passíveis de a provocar - é o que parece decorrer do texto redigido pelos dirigentes da Misericórdia em 1740, pelo qual se manda refrear a amizade da regente por uma criada, embora "nella como nas mais prelladas se nam possa presumir o perigo que se considera nas subditas terem amisades particulares"17. Por um lado, os mesários partilham de uma "denegação" geral, pois a homossexualidade feminina era desvalorizada (não sendo considerada pecado nefando por não haver derramamento de semente, deixou de ser objecto de inquirição por parte do Santo Ofício a partir de $1646^{18}$ ); mas, por outro lado, a legislação civil em vigor continuava a referir-se à sodomia feminina, crime passível de pena de morte pelo fogo ${ }^{19}$. Convinha, portanto, aos dirigentes da Misericórdia, não crer ou fingir não crer no pecado nefando feminino, expressão nunca utilizada, assim como o não é a palavra sodomia. Em quarto lugar, as órfãs são denunciadas pelas tentativas de contacto com o exterior através de várias modalidades: visitas não autorizadas, sinais feitos à janela, correspondência secreta. São ainda representativas as acusações de falta de respeito para com as preladas, o uso de vestuário ou adereços proibidos pelo regimento e a rudeza de modos. Em média, registam-se duas denúncias de órfãs por denunciante.

Quanto às porcionistas, não há dúvida que asfixiavam neste espaço claustral. É bem sintomático que o seu principal delito seja a comunicação com o exterior, vindo logo depois as inimizades que mantinham e/ou fomentavam. $\mathrm{Na}$ mesma proporção deste último, são acusadas de comportamentos impróprios, e, um pouco menos, de desrespeito às preladas e "grosseria" ou "aspereza". Com menos de $10 \%$ surgem as amizades, o uso de trajes e enfeites e, com pouca expressão, a falta às orações ou outras obrigações concretas. Em média, registaram-se 2,7 acusações por acusadora.

\footnotetext{
17 AMC, Livro das Visitas do Recolhimento, fl. 175.

18 Paulo Drumond Braga, A Inquisição nos Açores, p. 473.

19 Paulo Drumond Braga, "Dois casos de homossexualidade feminina...”, p. 87.
} 
Assim apresentados os diferentes desvios de comportamento, o que se ganha em sistematização e compreensão geral, perde-se no colorido, no pulsar do quotidiano, que se captam nas expressões usadas e nas situações descritas. Irei, pois, tentar uma aproximação maior a este universo de mulheres ${ }^{20}$. É claro que os relatos feitos são mediatizados: desde logo pela vontade das mulheres inquiridas, que só revelam o que querem e como querem, podendo deturpar os acontecimentos consciente ou inconscientemente; depois actúa um segundo filtro, os homens que recolhem os depoimentos, e que os podem condicionar ou pura e simplesmente omitir por não considerarem relevante o que era denunciado - o que faz com que se registem, afinal, apenas os desvios à norma acatada pelos homens, embora, por certo, a das mulheres, no plano ideal, não fosse muito distinta; finalmente, ao passar-se do registo oral para o escrito, o escrivão afeiçoa o texto, o que pode conduzir à distorção dos factos relatados.

$\mathrm{Na}$ primeira visita, em Abril de $1702^{21}$, não houve denúncias. Inquiridas sete recolhidas, todas afirmaram estar muito a seu gosto sem qualquer razão de queixa, mas já em Dezembro do mesmo ano, na segunda devassa ${ }^{22}$, surgem os relatos de desvios. E a visada é precisamente a regente, D. Filipa de Aguiar. Acusam-na de faltar ao coro e outros actos da comunidade, alegando que por ordem do médico só sairia da cela depois da 9 horas da manhã e das 2 horas da tarde; de se deitar logo depois da ceia, faltando à obrigação diária de ir rezar ao coro; de obrigar todas as órfãs a estar com ela, não as deixando ir dormir; de as compelir a varrer todo o edifício "aonde se estragaõ, rompem e maltratam", "avendo criadas que o poderão fazer"; e, finalmente, de consentir que a criada que trouxe consigo "descomponha" as órfãs. É evidente que a criada em questão, Maria da Fonseca, concita também o desagrado de muitas. Várias recolhidas, incluindo a porteira, D. Joana Coelho, testemunham que ela dissera que "se naõ fora por amor da Senhora Regente em todas [as órfãs] avia de dar muitas bofetadas", numa clara subversão da hierarquia estabelecida que a criada parece não ter interiorizado. A porteira e as órfãs passaram esta devassa incólumes. No final dos termos, a 21 de Dezembro, regista-se de forma lacónica: "Se fes a reforma e corressaõ necessaria pello Provedor desta Santa Casa"23.

Nas visitas seguintes, realizadas nos meses de Junho de $1704^{24}$, $1705^{25}$ e $1706^{26}$, não se exararam quaisquer resoluções tomadas. Nada haveria a reformar ou

20 O que se segue será, porventura, demasiado pormenorizado, mas optei por este registo porque disponibiliza informação rara e preciosa.

21 AMC, Livro das Visitas do Recolhimento, fis. 4-5v ${ }^{\circ}$.

22 AMC, Livro das Visitas do Recolhimento, fis. 6-8.

23 AMC, Livro das Visitas do Recolhimento, fl. 8.

24 AMC, Livro das Visitas do Recolhimento, fis. 8-9v ${ }^{\circ}$.

25 AMC, Livro das Visitas do Recolhimento, fis. 10-11.

26 AMC, Livro das Visitas do Recolhimento, fis. $l \mathrm{ll}^{\circ}-13$. 
ocultava-se a violação das normas? Impossível sabê-lo, mas alguns anos depois, em Janeiro de $1709^{27}$, os resultados são distintos. Vivem agora no recolhimento duas porcionistas e uma delas está claramente inadaptada. Preladas e recolhidas revelam que Ursula de Carvalho se recusa a fazer o serviço distribuído, ir rezar ao coro e dar graças no refeitório. Além disso, "descompunha" todas as companheiras com a sua "má lingoa". Contudo, algumas das inquiridas afirmam que isso acontece apenas porque Úrsula tem falta de entendimento. Confrontada com as acusações, afirma a visada que faltava ao coro devido aos seus achaques, não dava graças no refeitório porque fazia a sua própria comida (nem sempre às mesmas horas das outras) e que não varria por ser doente e por entender que como porcionista não era obrigada a tal serviço. A Mesa da Santa Casa impôs-lhe que actuasse exactamente como as outras tanto no coro, como nas refeições em comunidade e nas demais obrigações.

No ano seguinte o ambiente alterara-se, crescendo o incumprimento das regras ou criando-se fracturas internas que provocavam as delações ${ }^{28}$. Pela primeira vez, a regente, que continuava a ser a mesma, denuncia duas órfãs e as seis porcionistas existentes, enquanto a porteira se queixa da totalidade das "súbditas". Segundo as preladas e grande parte das recolhidas, muitas falam com mães e irmãos "e até com primos" sem licença da regente e tanto as órfãs como as porcionistas dão

"escamdallo quando na tribuna da igreja estaõ ouvindo misa falando desemtoadamente de sorte que quem esta na igreja repara na sua imquietasaõ e pouca reverencia com que devem assestir aos ofisios devinos e outrossim (...) se portã̃ com menos capasidade na caza do mirante estando cantando e gritando nella desemtoadamente naõ podendo deixar de serem semsuradas na vezinhansa".

Algumas porcionistas, ao referirem que é usual as recolhidas conversarem com pessoas não permitidas sem licença da regente, acrescentam que ordinariamente a portaria se encontra aberta. Uma outra esclarece que já foram muitas vezes repreendidas pela regente "do que ellas fazem pouco cazo". A órfã Tomásia Maria acusa a porcionista Josefa Caetana de lhe ter chamado "nomes imjuriozos sem cauza alguma sendo fora de oras amotinando o recolhimento acudindo a maior parte das pessoas delle". D. Antonia de Vilas Boas, porcionista, diz da mesma Josefa Caetana que "asenara da genella do mirante para a calsada

27 AMC, Livro das Visitas do Recolhimento, fis. 14-18.

28 AMC, Livro das Visitas do Recolhimento, fis. $18 \mathrm{v}^{\circ}-26 \mathrm{v}^{\circ}$. 
a serta pesoa" e, segundo D. Joana Maria, "asanou por muitas vezes da genella do mirante a sertas pesoas e o mesmo fes da tribuna da Igreja". O testemunho de Josefa Caetana não difere do geral: órfãs e porcionistas comportam-se mal na igreja, no mirante e na portaria. Também uma criada, "a Mendes"29, é denunciada por uma órfã por lhe ter respondido mal quando esta a repreendeu por falar da janela do mirante para a rua. Os preceitos de sisudez, gravidade, modéstia e recato exigidos à mulher de respeito são, pois, claramente violados. Perante estas revelações, a Mesa da Santa Casa da Misericórdia determinou que, sob pena de expulsão, não mais fossem ouvidas no coro e no mirante; que não falassem com ninguém, mesmo as mães, sem licença da regente; e que só a Mesa poderia autorizar conversas com pessoas não previstas no regimento. Ordenou ainda que a portaria permanecesse sempre fechada e que se alargasse a roda:

"Mandamos que a roda que se acha na caza da mesma portaria se amplie de sorte que por ella se posa receber hum cantaro de agoa com cuja grandeza fica capax de que por ella posaõ emtrar os mais comsumos e feita a dita obra se nã̃ abrira mais a portaria salvo para entrarem as pesoas presizas".

Quanto a Josefa Caetana,

"seja severamente admoestada lembrando-lhe que o dito recolhimento foi eregido naõ para Thiatro de galantarias mas sim para clauzura do recato e onestidade os quais milhor se demonstraõ com o recolhimento do que pellas acsões porque ainda que a faselidade as dispense por grasas poderá a simrezaõ condenallas por pezadas e asim se lhe emcarrega a emenda a penna de ser expulsa".

Ideias perfeitamente coincidentes com o discurso normativo da época relativamente à mulher ${ }^{30}$. $\mathrm{E}$ as medidas aplicadas, que mais não eram do que o exercício da violência sobre os corpos e sobre as vontades, terão obtidos os resultado desejados, pois na visita seguinte, em Junho de $1711^{31}$, só a regente declara que as recolhidas são em geral pouco obedientes, não sendo decretada qualquer reforma. Assinale-se, porém, que Josefa Caetana já não vivia no recolhimento.

29 As criadas são sempre tratadas pelos apelidos.

30 Sobre os pressupostos teóricos que estão por detrás da imprescindível clausura feminina, ver Maria Antonia Lopes, Mulheres, espaço e sociabilidade. A transformação dos papéis femininos em Portugal à luz de fontes literárias (segunda metade do século XVIII), Lisboa, Livros Horizonte, 1989, pp. 17-45.

31 AMC, Livro das Visitas do Recolhimento, fis. 27-30v ${ }^{\circ}$. 
Em Junho de $1713^{32}$ a regente é acusada por uma porcionista (D. Helena Pessoa) de ser omissa nas suas obrigações, deixando viver as recolhidas com muita liberdade. Perguntada se sabe se ela reparte as rações com igualdade, afirmou desconhecer porque a sua a manda cozinhar na cela. As criadas, Correia e Mendes, não satisfazem as suas obrigações. Diz uma órfã que, por se ter queixado, a dita Correia a tratou mal muitas vezes, assim como também descompôs a porcionista D. Antónia. Uma outra órfã acusa-a também de lhe dirigir "palavras desatentas e atrevidas por cuja cauza justamente vive queixosa". As porcionistas testemunham o mesmo: as duas criadas, principalmente a Correia, são muito atrevidas, mal ensinadas e desrespeitosas. Uma inquirida conta que ela, testemunha, fez uma camisa à Correia e que esta, não a achando a seu gosto, "a descompos chamando-lhe tola atrevida e confiada" porque lhe respondera não saber fazer melhor. Quanto às órfãs e porcionistas, mostravam-se demasiado rebeldes na opinião das preladas - trata-se, mais uma vez, de violação das relações de domínio institucionalizadas. A regente acusa a órfã Josefa Maria e a porcionista D. Antónia de provocarem inquietação com o seu mau modo, de lhe faltarem ao respeito e, ainda, de fazerem acenos para pessoas de fora e por vezes retirarem "a rota" da janela da cela de uma órfã doente onde iam com o pretexto de lhe assistir. A porteira é mais severa: sente-se "excandelizada do mao modo com que [órfãs e porcionistas] se retiravaõ da caza da portaria nas eucazioins em que naÕ achavaõ pronta a servente do convento para lhe fazer os seus recados, ao que soltavaõ pallavras altas e dezentoadas". O mesmo afirmam algumas delas, acusando as companheiras: que todas, sendo Ana Maria (órfã) e Teresa de Jesus (porcionista) as piores, vão à janela da sua cela fazer acenos para pessoas de fora; e que várias vezes descompuseram as colegas. Os acenos das janelas são também denunciados pelas criadas. Uma delas precisa que foram feitos da janela do mirante para um mascarado. Interrogadas sobre estas acusações, várias recolhidas admitem aos inquiridores que todas fazem acenos da janela de Guiomar, mas sem má intenção, porque feitos em comum; e que, de facto, foram proibidas pela regente, mas não lhe obedeceram totalmente.

Surgem, neste ano, e pela primeira vez, acusações de "amizades ilícitas" entre as recolhidas. A órfã Ana Maria e a porcionista Teresa de Jesus "tem entre sy amizade de que rezulta excandallo". A tão vigilante D. Helena Pessoa declara que por ser católica e de idade, vive escandalizada por "ver em muitas euccazioins as acsoins ilícitas e menos compostas entre a orfa Ana Maria e a persionista Thereza de Jesus". Também D. Antónia e Antónia Marcelina são acusadas de 
amizade escandalosa. Declara ainda a criada Concia que "prezume" haver amizade ilícita entre as duas Antonias, mas nunca viu fazer acção "menos composta". Levantada a devassa, a Mesa decretou repreensão geral, proibição terminante de acenos e da retirada das rótulas das janelas, que as criadas tratassem com cortesia as "pessoas maiores" e que Ana Maria, Teresa de Jesus, Antonia Marcelina e D. Antónia fossem repreendidas pelo provedor e castigadas pela regente sob pena de expulsão. Ter-se-ão aquietado? Vejam-se os testemunhos recolhidos no inquérito seguinte, precisamente um ano depois, em Junho de $1714^{33}$.

Nada foi apontado às criadas ou às directoras. Apenas uma órfã, Teresa Caetana, se queixou da regente porque a castigou com três dias fechada na cela "por cauza leve". As órfãs e porcionistas são na generalidade acusadas de desrespeitosas, de adoptarem modos desabridos e de se comportarem mal no coro, e a regente depõe ainda que, tendo proibido Joana Teresa de falar na portaria com certa mulher, ela lhe falou publicamente da sua janela para a rua perguntando-lhe por determinado sujeito, se tinha ou não ido para Lisboa e se voltaria. Os principais alvos de acusação desta devassa são essa mesma porcionista e a órfã Francisca Josefa, tomadas de amores. A regente declara que as surpreendeu "metidas em hua sella as escuras abrasadas ambas". As companheiras dividem-se: confirmam algumas haver murmuração a esse respeito mas nada ter sido testemunhado; outras são peremptórias, como D. Antónia Vilas Boas que as viu "duas vezes abracadas e em hua hicaziaõ junto a noute as achou inconstadas hua com a otra e por muitas e repetidas vezes as tem visto andar pello dito mosteiro com as maons dadas"; ou Apolinária Maria que "lhes viu fazer hua para a outra alguas acçoins tais que por peijo naõ declara”. D. Josefa Caetana de Vilas Boas confirma que tal relacionamento provoca "hum grave escandallo as pessoas do dito Recolhimento", e que embora ela nada tenha visto, ouviu dizer à órfã Teresa Caetana "que as ditas faziaõ accoins descompostas hua com a otra" e que Joana Teresa dissera "que como se acabasse esta vezita avia proseder pior do que athe aqui fazia, so para fazer andar em hua roda viva a Regente do dito Convento". Teresa Caetana declara que tal amizade ilícita causa

"excandallo e motivo a hua mermuraçaõ continua tanto assy que todas trazem as conssensias inquietas, o que por ivitar a Madre Regente fes vir dormir a sua sella a orfã Francisca Josepha a qual logo pella minham sedo se levantava e se hia meter na cama com a dita persionista Joanna Thereza aonde forã vistas estarem abracadas hua com a outra, o que hella testemunha sabe por lhe dizer hua prima que viu o que referido fica no tempo em que

${ }^{\text {J A }}$ A C, Livro das Visitas do Recolhimento, fis. 42-52. 


\begin{abstract}
assistia em o dito mosteiro, e que Joana Teresa tem dito varias vezes que se athe o tempo desta vezita conservava a dita amizade que hinda delia dahi por diante avia de continuar na mesma ainda com maior excesso".
\end{abstract}

As duas Antonias acusadas na visita anterior já não se encontravam no recolhimento. Permaneciam Ana Maria e Teresa de Jesus, mas nada lhes foi apontado. E o que testemunham as visadas? Francisca Josefa não acusa ninguém. Joana Teresa, confrontada com as acusações, afirma que D. Josefa Caetana a denunciou porque lhe tem inimizade e, além disso, alega, a órfã Teresa Caetana tem a mesma amizade que ela tem pela órfã Francisca Josefa. Terá sido, pois, o ciúme, o que movera Teresa Caetana e não a sua consciência inquieta. Por resolução de 18 de Junho, foi determinado que todas fossem repreendidas pelo seu comportamento no coro e que o mudassem, sob pena de maiores medidas. Quanto a Francisca Josefa e Joana Teresa, seriam admoestadas pelo provedor e castigadas pela regente, o que cumpririam sob pena de expulsão.

Decerto porque os mesários estavam preocupados com o que se passava no recolhimento, realizaram novo inquérito quatro meses depois ${ }^{34}$. Da regente, só a porteira se queixou, declarando que certa ocasião lhe tirou da roda um cesto com mau modo. Sobre as "súbditas", tanto a regente como algumas companheiras aludem às irregularidades já apontadas na visita de Janeiro: desinquietas no coro e restantes espaços e indiferentes às advertências da regente que afirma viver escandalizada porque lhe falam sem respeito. Segundo o testemunho da directora da instituição (mas só desta), existe agora escandalosa amizade particular entre Francisca Josefa e Teresa Caetana, já denunciado quatro meses antes por Joana Teresa que, entretanto, saíra para se casar. Não se registaram, no fim da devassa, as recomendações sugeridas pelos visitadores nem qualquer decisão da Mesa.

Um ano depois, em Novembro de $1715^{35}$, o quotidiano do recolhimento crispara-se muito mais, para o que talvez contribuísse o facto de aí viver cada vez maior número de mulheres: doze em 1711, treze no ano seguinte, quinze e catorze, respectivamente, por ocasião das visitas de 1714 e vinte e uma agora em 1715. Quatro porcionistas acusam a regente de dar "largas a todas", deixando-as estar no coro com perturbações, de só mandar escutar algumas quando falam na portaria, e de não fazer caso da amizade particular das porcionistas Apolinária Maria e Maria de Santo António. Apolinária, pois, também se tinha envolvido em sentimentos e acções que em Junho de 1714 tanto a

34 AMC, Livro das Visitas do Recolhimento, fis. 53-58.

35 AMC, Livro das Visitas do Recolhimento, fis. $58 \mathrm{v}^{\circ}-74$. 
perturbavam que "por peijo" não declarava. Pela primeira vez na história do recolhimento, a porteira, que se mantinha em funções desde a abertura da instituição, é também alvo de denúncias. Fá-lo a própria regente que a acusa de ser negligente nas entradas e nas visitas que não escuta. Outras recolhidas sustentam a denúncia, mas encontram palavras de compreensão pelo facto de ser mulher muito idosa. Nada foi apontado às criadas. Quanto às órfãs e porcionistas, as acusações são bem reveladoras da ineficácia da repressão. Os anos passam, as mulheres permanecem ou renovam-se, mas os desvios são inelutavelmente os mesmos. Neste final do ano de 1715, há "amizade ilícita", não só entre Apolinária e Maria de Santo António, como entre Francisca Josefa e Teresa Caetana - relacionamento já revelado nas duas devassas anteriores. Era desta amizade que troçava o papel satírico anónimo, provocando a bulha e o episódio de violência física já mencionados.

Além deste "crime", abundam as acusações de correspondência secreta, revelando que era impossível impor a estas mulheres a reclusão total. A órfã D. Margarida teria escrito ao estudante José da Cunha residente na rua Corpo de Deus. D. Josefa, porcionista, recebeu cartas de estudantes e acenou do coro a um outro. Segundo declarou uma testemunha, ela própria leu à porcionista D. Ana duas cartas de um estudante chamado Antão, mas "não achava nellas mais que huns comprimentos Lijeiros". E corresponder-se-ia também com António Lopes, pai do Dr. António de Andrade Rego. A porcionista D. Teresa, sobrinha da regente, carteava-se, também, com um tal Veríssimo Cordeiro. $\mathrm{Ou}$, nas palavras de outra recolhida, "assistia a Veríssimo cordeiro e vira que este lhe assanava por muitas vezes e que a dita lhe dissera que eram os assenos para ella D. Teresa". Também D. Antonia Luisa escreve para fora e fala com um frade que ela diz ser seu parente, tendo dele recebido algumas coisas com que ela comprara um capote. $\mathrm{Ou}$, ainda, no registo de outro interrogatório, fala sem licença com um frade bernardo, Bartolomeu Domingos, que diz ser parente, costumando este dar "sua caixa de tabaco a Porteira para se retirar". O pai de D. Antonia teria mesmo escrito à regente ao saber que a filha falava a um frade que não é da sua família e pedindo que fosse proibida e repreendida.

Mais estrepitoso é o que a regente relata sobre o ocorrido a 13 de Novembro desse ano: estando as irmãs Josefa de S. José e Benta Maria, ambas porcionistas, a falar na grade com Bartolomeu da Silva sem licença da regente, esta enviou uma recolhida como escuta. Quando ela chegou, as duas irmãs insultaram-na dizendo "lhe aviaõ de dar com cousa que he indigno de diser nem escrever". E acorrendo outras, a todas ofenderam declarando "que milhor porsedimento tinhaõ as recolhidas do Paso do Conde e que eraõ peores que as do Beco da Mostardeira" e tão alto o gritaram que se ouviu na rua e acorreu gente, o que gerou gravíssimo escândalo. 
Pensa a regente que as duas irmãs, por terem vindo contra sua vontade, "andaõ dando cauza a estas bulhas e ameassaõ a todas que delias se aõ de vingar sem pao nem pedra". O episódio foi confirmado pela porteira: costumam vir à porta falar a quem as procura sem licença da regente, a quem não têm respeito algum e ainda menos a ela, porteira, que confessa ter medo das suas irmãs; não cumprem obrigação alguma do recolhimento; estando as duas na grade falando ao dito Bartolomeu na presença de uma órfã na qualidade de escuta, a mandaram embora e, como esta recusou, a descompuseram com nomes sinistros que não pode dizer e acorrendo outras, também as insultaram em grande gritaria com escândalo da vizinhança e pessoas que passavam. Outros pormenores são acrescentados pelo Irmão Manuel Cabral, ourives, chamado a depor:

“Ouvira em sua casa tal gritaria e allarido na dita Portaria em o dia asima declarado, e que a Regente o mandara chamar da janela, que acodisse como Irmã̃ da Casa, e indo logo acudir lhe disseraõ todas estava a orfa Guimar com hum acsidente causado de a descomporem injuriozamente Benta Maria e sua irman e todos os visnhos se escandalisarã̃ e elle testemunha morando defronte a annos naõ ovira nem vira similhante susseso".

Além desta bulha do dia 13, houve ainda dois outros incidentes: Tomásia Maria, Joana Teresa, Josefa Caetana e a Correia, respectivamente antigas órfa, porcionistas e criada do recolhimento, entraram no edifício sem licença puxadas para dentro por cima da meia-porta ou postigo. E uma viúva desta cidade, D. Bernarda, entrou também sem autorização, achando a porta aberta por estar a regente com uma tecedeira medindo um pano. Esta devassa revela bem os níveis de incumprimento das regras e de agressividade que se atingiam, extravasando em violência verbal com recurso a gritos, ameaças, injúrias, obscenidades e escritos anónimos e culminando em violência física com "desconpusissoens e arranhadelas": violência de mulheres, mais inaceitável do que as dos homens por invalidar flagrantemente o arquétipo feminino.

Pela resolução de 4 de Dezembro de 1715, a Mesa emite ordens de prisão para quatro recolhidas, as medidas mais severas até então tomadas. Regista-se que as porcionistas Benta Maria e irmã

"por naõ terem obediencia a madre Regente e naõ comprirem o Regimento da Caza se fazem escandallozas de todas as Pessoas do Recolhimento e por serem de condissoins bravas saõ perturbadoras e nosivas a Comonidade a qual com excesso emjuriaraõ (...) e com tanta demasia que naõ so foi participada mas estranhada pela visinhansa (...). Porem usando com ellas de misericordia mandaõ que a Madre Regente as ponha em Prisaõ estreita 


\begin{abstract}
donde as nã̃ soltara sem ordem da Mesa sendo primeiro severamente amoestadas pelo Sr. Provedor para que não tomem a cair em similhante culpa $(. . .)^{\text {a }}$ Pena de serem expulsas".
\end{abstract}

Provada a correspondência que a porcionista D. Teresa tinha com um vizinho, acenando da janela e rótula, e que "intentara 1er hum pasquim a Teresa Caetana e se presume foi autora dele o que tudo provocou discussões de palavras que passaram a violencias de mãos", terá prisão rigorosa donde não sairá até ordem da Mesa e admoestação severa do provedor, sob pena de expulsão. Provado também que D. Antonia fala e escreve a um frade sem licença que parece não ser seu parente, o que escandaliza a comunidade e desgosta o pai, não mais comunique com o frade e receba rigorosa admoestação do provedor e prisão apertada donde não sairá sem ordem da Mesa. Além disso, determina-se que a regente vigie Francisca Josefa e Teresa Caetana, de imediato seja aplicada a rótula em falta, e, mostrando-se a porteira incapaz, pela sua avançada idade, ("sendo toda a vigi llanda taõ importante asim ao credito do dito Recolhimento como ao decoro das Pessoas delle"), seja deposta e nomeada a porcionista Bárbara Maria.

Segundo os termos da visita de Dezembro de $1716^{36}$, à excepção das amizades particulares, nenhum dos "delitos" revelados e castigados em 1715 se repetiu. Nesta altura só se denunciaram amizades, mas não as mesmas, pois surgira uma outra entre a órfã Teresa de Jesus e a porcionista Teresa Ferraz. A primeira era acusada de tais práticas, como vimos, desde 1713. A segunda era nova na casa. Francisca Josefa é mais uma vez acusada de amizade particular, agora com a órfã D. Ana, que sucedera a Joana Teresa e Teresa Caetana. Esta última ligara-se neste ano a Bárbara Maria, a recolhida que fora nomeada porteira no ano anterior, mas que não é assim designada nesta visita. E havia ainda um último par que se constituíra no ano transacto, as duas porcionistas Apolinária Maria e Maria de Santo António. Decerto que tantas amizades explicam a ausência de episódios de violência. Se é que tal profusão de revelações não é uma óbvia manifestação de violência pura. Note-se que Teresa Ferraz não se coíbe de denunciar o amor de Apolinária Maria e Maria de Santo António, assim como estas duas delatam Teresa de Jesus e Teresa Ferraz. Teresa Caetana revela estes dois pares. E Francisca Josefa e D. Ana acusam Teresa de Jesus e Teresa Ferraz. Abstiveram-se de denúncias Teresa de Jesus e Bárbara Maria. $\mathrm{Na}$ resolução tomada depois desta inquirição recomenda-se que o provedor e a regente corrijam essas mulheres porque "se trataõ com amizade taõ estreita, que motivaõ algum escandallo as mais pessoas". 
Treze meses depois, em Janeiro de $1718^{37}$, a regente é censurada por várias recolhidas: por vezes dá licença a certas porcionistas para que falem com pessoas que dizem ser parentes; parece ter medo de Apolinária, Maria de Santo António e Isabel Maria; não estranha nem castiga alguns excessos e palavras desentoadas; é mais branda para umas do que para outras; recebe as queixas mas nada faz; é frouxa ao permitir as pelejas entre uma órfã e uma porcionista; consente que se usem polvilhos e enfeites e, finalmente, não mostrou desagrado (muito pelo contrário, porque até abreviou a oração) quando os parentes das recolhidas trouxeram descantes ${ }^{38}$. Queixas há também contra a porteira que era agora Maria de Santiago, tendo D. Joana Coelho permanecido no recolhimento na qualidade de porteira aposentada. É a própria regente que acusa Maria de Santiago de permitir à filha, Teresa Gertrudes, falar a sós na roda com um seu parente. Além disso, dizem as recolhidas, tem por vezes modos desabridos e permite mais "largas" a umas do que a outras e leviandades na portaria, nomeadamente à filha e a Teresa Ferraz. A criada Silva é acusada pela porteira de ser de muito má condição, responder com descompostura, recusar fazer coisas de sua obrigação e "andar com infeitos a que pode chegar a sua pouca pocibelidade trazendo sapatos de salto de pao e picaros nos coleyrinhos das camisas".

Quanto às órfãs e porcionistas deste ano de 1718, são alvo de várias queixas. Comportam-se no coro com notável irreverência, donde falam para a igreja e onde jogam às cartas; uma menina que agora vive no recolhimento, sobrinha da órfã Luisa Antonia, causa alguma perturbação (principalmente na igreja); muitas são as que acenam das janelas e daí chamam moças para mandar a recados e pessoas que trazem coisas de venda ou até "outros bem escuzadamente". Além disso, demonstram grande desenvoltura cantando cantigas indecentes de que a vizinhança murmura, D. Ana tem muito pouca prudência no falar, causando escândalo ao falar alto e com "palavras malsoantes" e, por causa da inimizade que mantém com D. Josefa, "falaõ ou pelejaõ dizendo hua a outra palavras indignas". Algumas dormem juntas no mirante "com o perteisto de medo" e todas elas, com excepção das que entraram nesse ano, vêm à roda "nos dias de fazer" sem capelo e só com lenço, usam vestidos de cor, ouro, sedas, capotes encamados e polvilhos e com eles vão à grade. Luisa Antonia mantém amizade particular com Isabel Maria, sua prima. E o mesmo faz Francisca Josefa com Teresa Gertrudes, a filha da porteira e 4a amiga suspeita de Francisca. Teresa Ferraz faz leviandades na portaria, pois tem correspondência com o filho de Fradique

37 AMC, Livro das Visitas do Recolhimento, fis. $86 \mathrm{v}^{\circ}-98 \mathrm{v}^{\circ}$.

38 Terão vindo ao patim uns descantes em duas ocasiões, quando uma recolhida se foi para fora e quando o irmão de uma outra tomou o capelo. 
Lopes, falando com ele na roda quando este vem visitar as irmãs. A filha da porteira conversa com o parente Bernardo Manuel Gomes e este é continuo em lhe assistir com demasia da rua da Calçada para a janela do mirante. $E$ as irmãs D. Ana e D. Mariana falam longas horas com um estudante que vem com a mãe delas quando visita as filhas, o que é causa de escândalo porque se presume mal da tal mãe.

Confrontadas com estes factos, eis algumas justificações: afirma a regente que ela, a porteira e outras oito recolhidas dormem no mirante "por razaõ de haver no dito recolhimento grandes medos que ella também prezenseou e desde entaõ disimulou e desculpou o não dormir cada hua na sua cella". Admitem algumas usar polvilhos e vestes menos sóbrias, mas, esclarecem, só esporadicamente e nunca na portaria. Uma das criadas refuta as acusações feitas à directora, referindo que muitas vezes, pela meia-noite, anda a regente pelo dormitório espreitando para evitar que as suas súbditas durmam duas a duas. O que parece é que, neste ano de 1718, das amizades intemas se passara à busca de afecto no exterior, procurando-se dentro do recolhimento o descarregar de tensões tanto pela diversão como pela agressividade.

As determinações da Mesa foram duras: não se joguem cartas no coro nem nenhum outro jogo ou passatempo e as meninas, se as houver, nunca irão ao coro; se surgir desinquietação entre as recolhidas, logo a regente as separe e, finda a oração, as repreenda no mesmo local e em público, informando a Mesa de seguida; as que reincidirem terão oito dias de tronco ${ }^{39}$ irremissíveis; e se a regente esconder estas coisas será repreendida pela Mesa. Não mais passarão a noite no mirante; nunca duas recolhidas dormirão na mesma cela salvo se forem irmãs; só falarão na portaria com pais, irmãos e tios (só irmãos de pai ou mãe) e as que prevaricarem serão metidas no tronco por oito dias. A regente não consentirá que se tanja, cante ou dance com desenvoltura e nunca diante de pessoa de fora, pois deverão viver com todo o recato. Ficam proibidos trajes e enfeites profanos, sob pena de oito dias de tronco, sendo aplicada a mesma pena à que vier à portaria sem capelo cosido. As criadas trajarão com toda a honestidade e, não o fazendo, serão expulsas depois de oito dias de tronco. Também a regente se vestirá com toda a honestidade para servir de exemplo, sob pena de castigo ao arbítrio da Mesa. Os oito dias de prisão ficam, pois, instituídos como castigo corrente.

Ainda no mesmo ano de 1718, em Novembro/Dezembro, procede-se a outra devassa ${ }^{40}$. Nesta, só a porteira acusa a regente, declarando que permite à porcionista Isabel Maria falar com um estudante alegando ser seu primo. Já sobre a

19 O tronco era uma cela de isolamento para castigo usada nos recolhimentos e conventos.

•" AMC, Livro das Visitas do Recolhimento, fis. 99-120v. 
porteira, Maria de Santiago, as denúncias não faltam, girando na sua maioria à volta do relato de um episódio entretanto ocorrido que alvoroçara todo o recolhimento e revelando a conflitualidade crescente que grassava neste microcosmo.

Tudo começou quando se quis dispor de "hum tronco ou Caza piquena" ocupado por Angélica, criada de Maria de Santo António ${ }^{41}$. Esta não gostou e, reagindo intempestivamente, declarou que largaria tronco e cela, se necessário fosse, "porque não estava ao pão da Misericórdia", pois tinha mãe em Ceira que a sustentava 42 . Tal réplica provocou grande ira da porteira que se sentiu afrontada. Seguiram-se gritos e insultos. A porteira terá afirmado que Maria de Santo António devia a admissão no recolhimento a Francisco de Morais (o que mais não era do que "lançar-lhe alguma cousa em rosto", como se queixa a visada), "que se queriaõ saber o que ella era perguntassem a Antonio de Macedo" e que ela "era huma desavergonhada de Ceira". Respondendo a insulto com insulto, Maria de Santo António terá então acusado a porteira de ter mantido amizade ilícita e de adultério, pois a sua filha não era do marido mas de um tal Tomé ${ }^{3}$. Há quem afirme, também, que a porteira "anda em odio" com Apolinária e Maria de Santo António e que dissera que esta não casava por causa de "huns pontinhos que ela sabia", que a Mesa a vingaria dos insultos recebidos ou ela própria o faria nem que o inferno estivesse aberto para a receber, o que foi ouvido das pessoas de fora. Uma outra testemunha diz estar convicta de que a porteira está em ódio mortal com Maria de Santo António e "e se tem por certo que tras huma navalha na alj ibera dizendo que se a referida Maria de Santo António lhe disser alguma palavra pouco atenta, que com a dita navalha a havia de cortar". Além disso, "como por queixa, ou galantaria" tudo contou a Fr. Estêvão, religioso de S. Francisco, o que escandalizou quem

41 Segundo alguns testemunhos, a criada Angélica que ocupava a casa do tronco não era realmente criada porque, tendo servido Apolinária, esta dispensara-a, ficando então como criada de Maria de Santo António, mas na verdade não servia a ninguém pois se sustentava do que lhe trazia a mãe.

42 Maria de Santo António declarou que Angélica não era sua criada, "mas só se acoitava a ella e que se em algua cousa a servia lhe pagava, mas que naõ duvidaria que a chave se entregasse mandandoo assim o Senhor Provedor, e naõ só essa mas taõbem a da sua celia e se hiria para Ceira, pois naõ estava ao tostaõ da Misericordia, e destas palavras se irou tanto a porteira, que lhe disse que ella taõbem naõ nessessitava do tostaõ da Caza e que se fosse para Ceira, que la apuraria o credito e que naõ andaria com tanto frio, e que ella Maria de Santiago naõ viera ao Recolhimento apurar o seu credito".

43 Desculpou-se depois dizendo que o soubera por Clara que, por sua vez, o ouvira a Apolinária e que também o dizia a ex-porcionista Teresa Ferraz, que agora vive em Lisboa. Testemunho de Clara: Apolinária, zangada com a porteira por ter dito mal de Maria de Santo António, foi à cela dela, Clara Maria, e disse-lhe que se Maria de Santo António se quisesse despicar, poderia ter dito que a porteira se havia desonestado, pois tinha andado amancebada com certo homem casado e que a filha não era legítima. Clara, que era amiga da porteira e filha, foi de imediato à cela desta transmitir-lhe o que ouvira e pedindo segredo, mas ela foi logo contar à mãe. 
ouviu. Fez tal gritaria por a terem acusado de adultério, que parecia fazer gala disso porque o contou na portaria às pessoas de fora ${ }^{44}$. Respondeu, por exemplo, a uma mulher que lhe perguntava pela filha, que "andava cada ves mais bizarra, pois tinha ainda pay, quando ella cuydava estava fallecido, e que com tal pay, devia andar mais alegre e bizarra, mas que a desavergonhada, e porquinha de Ceira havia de ser castigada" pela Mesa; e se não fosse, havia paus, mãos e facas "porque se havia de vingar inda que visse o inferno aberto".

Há quem denuncie a porteira por ser de "terrível condição", "de aspera condição", facilmente descompor a todas, falar mal de algumas, "dizendo para pessoas de fora que eraõ humas doidas" incapazes de tomar estado, "andando as pessoas deste Recolhimento em Ranchos". E, explica uma recolhida, é porque favorece as que dormem no corredor de baixo (Teresa Gertrudes, Maria Gomes, Clara, Eufrásia e as três irmãs do Dr. Inácio do Vale), deixando-as falar livremente na roda e porta, que se formaram facções, sendo uma afecta à porteira e outra à regente. Também a acusam de revelar muitos descuidos na sua ocupação "pois para a Roda não vem Logo pella menhã, mas ao dipois de sete, e outo horas de maneira que Livremente podem hir fallar ao Rallo da porta, e ainda á grade e Roda, que muitas vezes tem esquecido fecharse". Denunciam-na, também, por permitir às suas "parssiaes" Benta Maria, Josefa de S. Francisco e Eufrásia falar sem capelo, como se impôs na visita passada, e de ter ameaçado "tirar a lingoa" a quem na visita se referisse à filha. A porteira do recolhimento é, pois, neste ano de 1718, a mais contestada das recolhidas, mas também outras prevaricaram aos olhos de algumas companheiras, revelando-se um ambiente muito crispado. D. Ana Maria e Apolinária não se falam há mais de um ano porque tiveram uma zanga e trocaram palavras injuriosas. Já depois de se haver principiado a visita, travaram-se de razões no próprio coro D. Ana Maria, a órfã Francisca Josefa e a porcionista D. Antónia. E a esta foi necessário que a regente a trouxesse para a sua cela e se não aquietou "sem embargo de se lhe dizer por ella testemunha, que visse o lugar em que estava diante de nossa senhora, ao que ella respondeu com braveza, mas que estivesse el Rey”. Apolinária é acusada por D. Ana Maria e irmã (D. Mariana Teresa) de ser "Larga e descomposta de sua Lingoa", acusar a primeira de Ladra, propalar que a porteira se desonestava com certo homem e que a filha não era de legítimo matrimónio, intimidar a regente e declarar que, à excepção do provedor, todos membros da Mesa eram "savandisse" 45 . da filha.

44 Uma das inquiridas afirma que foi a própria porteira que inventou a história da ilegitimidade

45 Uma outra recolhida depõe que Apolinária chamara aos mesários "huma pedintaria ou piolharia, palavra de que naõ está muito certa, mas que foy huma assim semilhante como em desprezo". 
Os inquiridores passam a perguntar a todas se houve alguém que aludisse desrespeitosamente aos mesários.

Mas as acusações continuam, demonstrando a contínua busca de diversão e de contactos com o exterior. D. Ana Maria mantém correspondência e troca de presentes com o estudante Manuel Ferreira que vai para frade, mas frequenta o recolhimento com o pretexto de ver a irmã. Teresa Gertrudes, a filha da porteira, cultiva amizade e correspondência com Manuel Gomes, beneficiado em S. Tiago, que, com a desculpa de serem primos, com ela conversa a partir do patim da igreja de $\mathrm{S}$. Tiago e chegando ao cúmulo de a presentear com cinco côvados de baeta para um roupão. Francisca Maria mostra inclinação por José Vilas Boas que a vem ver com o pretexto de visitar as irmãs (e este mesmo sujeito já procedera de igual forma com a ex-porcionista Teresa Ferraz). E algumas outras, diz a porteira, com inquietação e desenvoltura, estiveram à janela que dá para a casa dos Coutinhos da Praça nos dias em que lá se fizeram umas comédias. Além disso, muitas delas usam polvilhos e pentes na cabeça, vão à portaria sem os capelos pregados, jogam cartas e comem no coro e não se confessam com a regularidade devida por não virem os confessores. Nenhuma amizade ilícita entre elas foi denunciada. Quanto às criadas, só cinco recolhidas as referem: duas pela forma como se apresentam - andam em cabelo em vez de trazerem coifas e quando trazem capelo usam fitas; e três por serem desobedientes e desrespeitosas. Um das recolhidas, mas só ela, acusa ainda o mesário Estêvão Ribeiro de frequentar a portaria.

Interrogadas com perguntas precisas dos inquiridores que já recolheram informes dos depoimentos anteriores, não faltam justificações ou mesmo negações. A porteira aposentada, por exemplo, confirma que vem à Roda um estudante filho do pintor João de Sousa falar com a prima, mas desta comunicação não presume mal nem resulta escândalo. E muitas são as que absolvem totalmente Maria de Santo António, atribuindo todas as culpas à porteira Maria de Santiago. Embora esta devassa revele uma atmosfera pesada, de grande violência explícita, só em 11 de Janeiro de 1719 foram tomadas decisões: que a porteira seja pelo provedor admoestada e advertida que a todas trate com amor e caridade; que na portaria cumpra o que foi determinado na visita passada (capelo, escuta e prévia licença da regente); que cesse o escândalo que resulta do ódio que mostra ter por Maria de Santo António e que lhe perdoe por amor de Deus toda e qualquer ofensa, dando-lhe os braços quando esta lhe pedir perdão como abaixo se ordena,

"advirtindo que se não prova nem mostra que a sobredita porcionista Maria de Santo António dissesse direitamente palavras injuriozas contra ella e que mais claramente se mostra que a mesma porteira com a ira com que rompia em queixas, e palavras injuriozas contra a porcionista fallando 
com algumas pessoas assim do Recolhimento, como fora delle, parece queria fazer mais publica a sua diffamaçã̃".

Também perdoará qualquer injúria a Apolinária, "lembrandosse só da obrigaçaõ de perdoar injurias e não das paixões humanas para ameaços de vinganças". Maria de Santo António e Apolinária, no coro e na presença da Regente, órfãs e recolhidas, pedirão de joelhos perdão à porteira, e que tudo o que dela disseram têm por falso. Serão também repreendidas e cada uma, em casa de tronco separada, seja presa oito dias por se terem mostrado desobedientes no caso da entrega da chave e porque a primeira foi soberba e a segunda desrespeitosa à Mesa. Porque os "mexericos" de Clara Maria foram a principal causa destes "enredos", "pois da sua chocalhice rezultou a poeyra que se Levantou, sendo certo que aquella pessoa que na prezença da injuriada refere as palavras injuriozas, que em auzencia se proferirão, he a que fas a mayor injuria", seja gravemente repreendida e presa por vinte dias em outra casa de tronco - o mais severo castigo até agora aplicado. Ordenou-se ainda que Teresa Gertrudes fosse admoestada para que, sob pena de expulsão, não trate nem comunique com o beneficiado Manuel Gomes, mesmo na presença da mãe; que Francisca Maria não fale com José Vilas Boas ainda que na companhia das irmãs dele; que a regente zele por tudo isto com cuidado e também não permita que se fale das janelas, nem acenem, nem troquem entre si palavras desentoadas, fazendo observar o que se tem ordenado nas visitas "e se ordenara em os Cappitolos que se haõ de fazer em livro separado para estar em seu poder".

Só dois anos e meio depois, em Junho de 1721, se procedeu a outra devassa ${ }^{46}$, onde se apurou que D. Filipa de Aguiar, a regente de sempre, é frouxa, não se sabendo impor e permitindo certas visitas proibidas. Mas muito mais graves são as acusações feitas à porteira, que continuava a ser Maria de Santiago. Apropria regente a denuncia por permitir que as recolhidas falem na portaria sem sua licença e com pessoas proibidas pelo regimento e pela visita passada, por deixar que a filha fale e escreva ao beneficiado Manuel Gomes, com continuação e escândalo, e por autorizar a órfã Maria Josefa a conversar particularmente com o seu parente, o Dr. Alexandre Ferreira. Embora estes factos sejam corroborados por várias recolhidas, outras órfãs afirmam que Maria Josefa fala ao Dr. Ferreira com autorização de D. Filipa e que recebe também visitas de um estudante que não tem com ela qualquer parentesco. Denunciam ainda que a regente consente que a órfã Josefa Maria fale com um clérigo a quem chama tio, assim como também autoriza a porcionista Sebastiana da Encarnação a conversar com um 
seu parente, o padre Bernardo que é capelão da Sé. De um modo geral, as recolhidas usam polvilhos, lêem as cartas que lhes chegam e que não passam pela directora e não se coíbem de lhe responder com menos comedimento e cortesia. A inquietação no Coro não foi resolvida e as acusações à filha da porteira são numerosas, devido ao seu contínuo relacionamento com Manuel Gomes. As criadas são descorteses, afirma-se. E a servente (criada de fora) é acusada de levar as cartas da porteira e da filha a Manuel Gomes. Inquirida sobre o assunto, a servente confirma o seu papel de intermediária, mas diz que o fez por se tratar de um parente.

Tais testemunhos revelam que de nada valeram as admoestações e os castigos decretados em Janeiro de 1719. Sentenciaram-se, então, as medidas mais drásticas exaradas neste livro: a expulsão, no prazo de quatro dias, da porteira e da filha - a primeira porque permite, contra o decreto da visita passada, que falem com pessoas proibidas tanto na sua presença como ausência e sem informar a regente; a segunda porque, com escândalo de todo o recolhimento, tem correspondência falada e escrita com o beneficiado Manuel Gomes, o que lhe fora proibido já por decreto da visita anterior. Às restantes, recolhidas e criadas, foram aplicadas apenas censuras públicas, avisando-se Maria Josefa e Sebastiana da Encarnação que seriam expulsas se voltassem a falar com os ditos sem licença da Mesa. Também a regente foi advertida para zelar e castigar e, no que não puder acudir, dar conta à Mesa. A porteira foi efectivamente expulsa. Em Agosto de 1723, na visita seguinte ${ }^{47}$, ocupa o cargo Maria de Nazaré, que nas devassas anteriores não vivia no recolhimento.

Nesta devassa de 1723, acusa-se a regente de parcialidade, sobretudo com Josefa Maria, Josefa dos Anjos e Francisca Teresa, a quem permite falar na portaria sem capelo, enquanto às outras censura publica e asperamente pelo mesmo motivo; afirma uma porcionista que também não corrige as que no coro estão sem a decência devida, nem as que durante a noite andam com gritarias e estrondos; há quem pense, ainda, que a directora mantém mau relacionamento com a porteira porque cada uma tem as suas preferidas. Por sua vez, a regente acusa a porteira de dar "mais largas" a umas do que a outras e de andar "em piques com ela", fazendo-lhe entender que não devia assistir na portaria pois não era o seu lugar. São visíveis, pois, conflitos de autoridade entre as duas preladas. Também as órfãs e porcionistas censuram à porteira a sua parcialidade. Além disso, diz uma testemunha, deixa que se fale a pessoas de fora e permitiu a uma órfã vir à grade falar sem capelo e empoada de polvilhos. Várias órfãs são nomeadas: segundo a regente, Maria Josefa foi por três vezes falar à portaria sem licença dela a um primo estudante; Maria Josefa, Eufrásia e Josefa Maria andam zangadas há cerca de

${ }^{47}$ AMC, Livro das Visitas do Recolhimento, fis. 131-139v․ 
dois anos e, desde então, vivem malquistas, picando-se por cantigas e palavras, do que resulta escândalo, embora ela, regente, tivesse recorrido aos religiosos missionários para as confessar e reconciliar; afirma, ainda, que Teresa de Jesus tem muita culpa "de haveram algumas rezões entre as Orphas e Porcionistas, por ser chocalhera e mintiroza". No testemunho da porteira, Josefa Maria e irmã estão demasiado tempo na grade a conversar com a mãe, um tio religioso e “outras pessoas chamadas Primos” e recusam sair de lá sem ordem da regente; certa vez, acrescenta, repreendendo Josefa Maria por ter dito palavra pouco decente na portaria,

"Ihe respondeo a dita orphã que quem era ela Porteira para a reprehender, mostrando nisto huma grande soberba, e ser de má condição e ma lengoa, e que esta tal orpha vive com odio havera dous annos com outra orpha Eufrazia Maria em forma que da escándalo a todo o Recolhimento e a mesma teima tomou com a orpha Maria Jozepha por ser amiga da dita orpha Eufrazia”.

Note-se a violência contida nas palavras usadas: soberba, má condição, má língua, ódio, escândalo. Acusa ainda Josefa dos Anjos de ser soberba e altiva "por se achar favorecida da inclinaçaõ da Madre Regente" e declarações de teor semelhante são produzidas por órfãs e porcionistas. A porcionista que suscita mais censuras é Sebastiana da Encarnação. No testemunho da regente, fez gritarias na cela porque a porteira a repreendeu por ter ido à portaria falar a uma criada de estranhos "em anaugua branca de algodaõ que he saya que comumente costumaõ traser interinamente dentro do Recolhimento". Nas declarações da porteira, muitas vezes a advertiu porque fala com muitas pessoas "pellos muitos conhecimentos que tem" e ela recebeu sempre mal as advertências, especialmente quando foi falar a uma criada vestida com anágua branca (que só ela usa) de que resultou ir para a cela aos gritos tão altos que inquietou todo o recolhimento e vizinhança. A órfã Maria Josefa declara também que ninguém mais usa saia branca como ela e que, embora continue a rezar no coro, Sebastiana reza as novenas na cela onde junta todas as órfãs e porcionistas e ela, testemunha, julga que esta separação se deve ao ódio que tem a Josefa de Santo Agostinho. Esta última afirma que tendo dito a Sebastiana que não devia ir tanto à portaria, ela lhe respondeu que quem não tinha conhecimentos não tinha estimações. Também Apolinária Maria é censurada por assistir continuamente na cela de Sebastiana da Encarnação, e porque, tomando as dores desta, disse que em três dias haveriam de pôr fora a porteira ou, noutra versão, que ela e Sebastiana haviam de expulsar a porteira com um pau. No seu interrogatório, Apolinária declara que foi por motivo de doença que Sebastiana começou a fazer novenas na cela com outras, a quem não chamou, tendo estas acorrido por sua devoção. 
Esta devassa revela ainda um episódio ocorrido na portaria com a mãe de uma órfã: a mulher, batendo na porta e gritando, terá dito que todas eram umas porcas, umas tolas, umas desavergonhadas e falsárias, dando a entender que todas tinham tido culpa na recusa de admissão no recolhimento de uma sua filha. Além disso, também um religioso da Ordem Terceira gritara mais que uma vez na portaria porque a regente tinha castigado a sua sobrinha fechando-a na cela por lhe ter respondido sem respeito. As criadas são, como tantas vezes antes, acusadas de desrespeito e descortesia.

Só em Maio do ano seguinte (1724) se tomaram decisões. Sob pena de expulsão e em presença de todas no coro, Apolinária pediria perdão à porteira do agravo que lhe fez e a prelada lhe perdoaria com toda a caridade. Também sob pena de expulsão, Sebastiana não mais apareceria em lugar público de saia branca nem faria as devoções com outras na cela. Nunca mais dormiriam duas na mesma cela salvo irmãs ou, por exemplo, a neta da porteira. Porque a Mesa estava inteirada que algumas se confessavam na grade da portaria com os confessores que entendiam e não com aqueles que a Mesa determinava, que são os Padres da Companhia, que isto não mais se fizesse, sendo a porteira severamente tratada se o consentisse. E porque a Mesa sabia também que não se vestiam com a devida honestidade, de que se poderia passar a maiores excessos, cuidaram em inquirir sobre o vestir das órfãs e porcionistas do recolhimento da corte e cidade de Lisboa; e, sabendo-o já, determinavam que, sob pena de expulsão, a regente e a porteira nas ocasiões públicas (confissão, comunhão, idas ao comungatório ou à portaria) vestissem de cor honesta com seus capelos ou, se preferissem, usassem capotes de cor também honesta como roxa e azul ferrete; que as órfãs nas mesmas ocasiões trajassem hábitos de estamenha escura com sua correia cingida e toalhas fechadas brancas e sem rendas, à imitação das Terceiras do Carmo e, querendo usar de outros vestidos, estes fossem de droguete, serafina ou baeta de cores honestas como âmbar ou pinhão ou, se trouxessem capotes, seriam das mesmas cores dos das madres; que as porcionistas andassem de seculares, contanto que não usassem cores garridas ou desonestas; e ninguém no recolhimento usasse seda, fitas, sinais e polvilhos.

Passaram três anos e meio e novamente o recolhimento é alvo de um inquérito, em Dezembro de $1727^{48}$. Vejam-se os resultados: a regente é acusada de não ter repreendido certas porcionistas (que já saíram) que de noite falavam das janelas para a rua e para a parte do rio e que fora frouxa e descuidada no tempo em que esteve no recolhimento uma sua sobrinha; tem tido por vezes omissões,

48 A MC, Livro das Visitas do Recolhimento, fis. 140-159v ${ }^{\circ}$. 
afirmam outras inquiridas, pois quando a órfã Rosa Maria deu uma bofetada na porcionista Angélica Maria, não a castigou, e também nada fez quando há pouco tempo as órfãs Josefa da Conceição e Mariana da Conceição tiveram uma briga na portaria; permite também inquietações no coro e as ladainhas e mais obrigações não são feitas a horas certas; além disso, é tão amiga das criadas que elas não fazem o serviço e chega a mandar as órfãs aos recados em vez de incumbir as criadas. Declaram ainda algumas testemunhas que só quando soube que ia haver visita começou a cuidar das suas obrigações, vigiando as recolhidas e fechando a horas portas e janelas. Porteira e regente acusam-se mutuamente. Diz aquela que a regente não leva em conta as suas observações e esta afirma que a porteira é mulher de muito má condição, o que provoca inquietações, pois raro é o dia em que não há ralhos. Queixa-se ainda a regente de que a porteira a desrespeita, autoriza conversas suspeitas sem sua ordem, abre a portaria sem ser necessário e despede parentes de outras recolhidas "por naõ serem do seo genio". Outras mulheres denunciam o mesmo, retratando a porteira como pessoa grosseira e desequilibrada: de má condição, mulher sem assento nem propósito, louca, ridícula, muito brava e "imcapax de se poder sofrer", é indigna da ocupação que tem. Profere "pallavradas" que escandalizam toda a gente, canta sem propósito, provocando riso e murmuração, e parece não estar em perfeito juízo. Trata muito mal a regente e as recolhidas com palavras injuriosas que provocam brigas e inquietações, descompõe pessoas que vêm à portaria, conta coisas particulares que se passam no recolhimento e consente, por peitas que recebe, que algumas falem com gente de fora.

Alguns episódios protagonizados pela porteira são também relatados: permitiu que uma recolhida (que já saiu) falasse com pessoa suspeita e, sendo advertida para que não deixasse, "respondeo que tinha filhos e Nettos e naõ queria que por esta cauza se vimgassem nelles"; vindo ao recolhimento um frade falar com a órfã Francisca Teresa e a porcionista Francisca Maria, e não o consentindo a regente, ela arranjou meios para que se falassem; quando a regente proibiu a órfã Rosa Maria de falar com Manuel Coelho, também a porteira os deixou conversar muitas vezes; numa ocasião, estando os Padres da Companhia confessando, deixou entrar dez ou doze mulheres sem licença por cima da meia porta; certa vez, pelo Entrudo, deixou divertir as que estavam dentro com os que estavam fora e com tal excesso que motivou escândalo; consentiu até há pouco tempo que viesse a este convento um certo João Baptista, que de presente está preso, falar com algumas recolhidas; deixa que o marido de Páscoa Maria fale com quantas quer; vindo à portaria alguns estudantes, e sendo advertida que avisasse a regente, recusou porque a regente não era capaz; outra vez, chegando à portaria um homem em trajo de mulher, ela chamou certa pessoa (que já saiu do recolhimento) para 
lhe falar, apesar de advertida que era homem e de má suspeita. Vemos, pois, uma porteira vulnerável às pressões do exterior, sejam elas suborno ou ameaças.

Nesta visita a órfã mais visada foi Maria Teresa que a regente acusa de desrespeito por ela, chegando a rogar-lhe pragas. Outras inquiridas contam que é rebelde e se corresponde com um estudante por nome Gualter Borges com o fim de se casarem; que usa a janela da cela da porcionista D. Josefa Vilas Boas para se verem e que dessa e de outras janelas faz acenos e escarra para estudantes e outras pessoas suas conhecidas. Por sua vez, D. Josefa Vilas Boas pedia que lhe escrevessem cartas de amor ao cura de S. Tiago, ao irmão do padre Manuel Pinto e a um estudante que dizem ser de Lisboa, ou, noutros testemunhos, correspondia-se com dois clérigos e com dois estudantes; e porque D. Josefa é analfabeta, quem lia e escrevia as missivas era a órfã Josefa dos Anjos que já não está no recolhimento. Também Jacinta Luisa se carteava com José de Carvalho, filho de Simão Femandes de Carvalho, a fim de se casarem, o que os parentes dela estorvam. A acusação de amizade suspeita entre recolhidas, que desde Janeiro de 1718 se não fazia a nenhuma, é novamente proferida: Rosa de Jesus mantém amizade particular com a porcionista que dorme no quarto em frente, Jacinta Maria. Na sua generalidade, as recolhidas continuam a vestir cores "desonestas", a usar pós no cabelo e a ir à grade sem capelo cosido. A coacção sobre a aparência que, manifestamente, visava abafar toda e qualquer marca de sensualidade, nunca foi eficaz. Ano após ano estas mulheres desobedecem e obstinadamente contrariam os códigos estabelecidos. As criadas, uma vez mais, são malquistas pelo desrespeito e desobediência e, também elas, pela pouca honestidade no vestir e toucar.

Por resolução de 14 de Março de 1728, a porteira foi despedida, a regente advertida para que com mais fervor e vigilância satisfizesse ao bom regimento e ordenou-se que Rosa de Jesus e Jacinta Maria fossem separadas, mudando-se uma para o corredor de baixo. Sob pena de imediata expulsão, pois já haviam sido censuradas em anteriores visitas sem que tomassem emenda, decreta-se que permaneçam sós nas suas celas durante as horas do silêncio (para que não resultem conjecturas), e todas observem o regimento, cessando as cartas, os pós na cabeça e os trajes desonestos, a inquietação e desoras no coro (que será sempre às trindades), as conversas com pessoas proibidas e sem capelo fechado. Decidiu-se, ainda, por não serem necessárias três criadas, o despedimento da que fosse menos útil49, nomear a porcionista Josefa de Santo Agostinho, viúva

49 Uma órfã declarara que não eram precisas tantas criadas por vir de fora a comida feita para a maior parte das pessoas que vivem no recolhimento, pois as criadas só cozinhavam para uma órfã. 
do irmão Maurício de Santiago, porteira do recolhimento e, finalmente, criar o lugar de mestra que o regimento prevê e a regente pediu para educação e boa doutrina espiritual e temporal, provendo nele a porcionista Sebastiana da Encarnação com 2.400 réis mensais. Segundo os resultados das devassas de 1721 e 1723, Sebastiana não era um modelo de virtudes, à luz dos critérios da Mesa, mas nesta última visita ninguém a acusou. Não podemos deixar de recordar a sua actuação ao atrair as companheiras à cela, o que parece ser uma estratégia de criação de uma clientela. Talvez isso explique a ausência de denúncias neste ano. Lembremo-nos, ainda, que em 1723 há testemunhos sobre os muitos conhecimentos que tem, e de que se vale, e sobre a sua hipotética capacidade para conseguir a expulsão da porteira. O certo é que foi nomeada mestra do recolhimento.

Após esta resolução, o livro em análise apresenta um longo hiato de 13 anos. Saltamos, pois, para a inquirição de Junho de $1740^{50}$. Nesta altura, Sebastiana da Encarnação, a antiga mestra, agora com 52 anos de idade, é a regente do recolhimento e, pela primeira vez, o comportamento da directora é notoriamente desviante. Acusada de rudeza, parcialidade e imprudência, o que mais indigna, contudo, é a estreita amizade que mantém com uma criada,

"o que escandalisa desde que foi porcionista e sendo mestra athe agora que he Regente sem ser possivel fazella separar por mais que a madre Regente defunta por isso trabalhou e que suposto nisto nam haja pecado comtudo ella dita madre nam peca de ignorante e sabe que nisso reparam todas e que reparando em cousas delia testemunha como ter hum roupam verde e cousas semilhantes, em si e na dita Angelica nam repara em cousas maiores".

A amizade especial e escandalosa é denunciada por muitas, incluindo a outra criada, embora todas recusem acreditar que seja pecaminosa. Alguns testemunhos fornecem pormenores: Angélica fica na cela da prelada até às $23 \mathrm{~h} 30 \mathrm{~m}$ e, embora tal amizade possa não ser ilícita, dá mau exemplo "ás meninas que querem ter amizades"; é reparável tanta amizade e tanta habitação com a criada, a quem conta todos os seus particulares; todas se escandalizam quando a regente repreende as súbditas por terem amizades; castiga segundo a vontade de Angélica; não deixa que entrem nas celas das outras e até no mirante as manda apartar, mas toda esta comunicação que proíbe, a tem com a criada a quem

"deixa trazer vestias brancas como as meninas, e outras de camelam lavrado cordoens cadeados e o ouro que tem e huma saya quase encamada, e quando a madre Regente tem visitas de clérigos ou frades, a dita criada vai 
primeiro tomallas muitas vezes e depois ela e da escandallo em a ter na sua cella de noute e de dia, mas não presume que haja pecado nem tem motivo para o entender".

A porteira, que é Luisa Antonia, mulher de $44 \operatorname{anos}^{51}$, só é acusada por uma órfa e por uma criada por abandonar a portaria e ser um pouco "mole". A mestra, como já foi referido, é alvo de insatisfação generalizada. Era ela D. Josefa Caetana de Vilas Boas, veterana no recolhimento, pois nele vive desde 1713 , então com 19 anos. Em todos estes tempo de instituição nunca aprendeu a 1er e a escrever, não conseguindo, sequer, assinar o nome. Vimos que em 1727 foi acusada de trocar cartas de amor com três ou quatro homens diferentes. Nas palavras da regente, é como sempre foi: faladora com liberdade, tendo suas histerias. Além disso, nada ensina porque não sabe o necessário e porque é muito achacada dos olhos, "mas tudo o referido fas por genio e falta de juiso de que sempre foi notada (...) e por isso não tem culpa". No testemunho da porteira, tem génio pouco agradável, orgulhoso e pouco modo de ensinar e por causa da moléstia dos olhos esteve impedida muito tempo de ensinar, mas agora vai para a casa de lavor. Tem "genio de embrulhadora", afirma uma órfã. Que conhecimentos domina a mestra, afinal? Apenas coser e fazer botões "e isso sabem quase todas e quando foi provida foi por esmola e não para ensinar", esclarece Luisa Josefa e, diz Joaquina Antonia, "está pronta para ensinar o que sabe, mas como todas sabem o mesmo, ninguém aprende"; provoca inquietações pelos seus ditos, dizem também, mas "he boa mulher"; "como tem pouco juizo, tudo se desculpa"; "não é capaz para o cargo porque não sabe nem tem modo para ensinar o pouco que sabe e tem génio terrível com o qual muitas vezes inquieta as meninas, mas tem necessidade e bem empregada é a esmola que lhe fazem".

Quanto às órfãs, a ovelha negra é Joaquina Antonia, acusada de amizade pecaminosa com a porcionista Rosa Maria, em cuja cela vai frequentemente dormir, andando sempre as duas juntas e demonstrando ambas ciúmes. Dois outros pares são acusados de "amizade leve": Bárbara Teresa e Maria da Trindade e Josefa dos Anjos e D. Teresa de Loné. Por fim, são apontadas todas as que possuem cordões, cadeados e botões de ouro, por não se eximirem de os trazer, e três recolhidas por não terem hábito, remediando-se com os das colegas que pedem emprestados. É claro que a criada Angélica foi alvo do rancor de muitas, mas também a servente se viu acusada de "responder com asperesa que só lhe falta dar com hum pao nas meninas", de ser "huma espingarda e so serve as

51 Tinha sido órfa do recolhimento entre 1718 e 1721 e seu pai fora ourives e Irmão da Misericórdia. Em 8 de Novembro de 1745, tendo apenas 49 anos de idade, conseguirá a aposentação por achaques e velhice com o ordenado de 1.600 réis mensais (AMC, Acordãos $4^{\circ}, \mathrm{fl} .223 \mathrm{v}^{\circ}$ ). 
que quer", de só o fazer de boa-vontade à regente e a Angélica, pois quando a mandam buscar alguma coisa ralha muito e o sabe a rua toda, fazendo o que lhe pedem só no dia seguinte e, ainda "ontem, trazendo peixe para algumas, deixou a mestra sem jantar".

Instadas com perguntas concretas dos inquiridores, as visadas justificam-se: quanto a ouro, só o usam nas orelhas "e alguma cousinha no pescoço"; em geral trajam vestidos honestos, excepto alguma vez que vestem saia ou capote usados para acabarem de romper; "que suposto raras veses haja escutas he por nam aver estillo ha muito tempo de havellas". A este propósito a regente esclarece que, como só falam com pais, irmãos e mulheres, não há escutas, que nem todos os escritos passam pelas suas mãos e que todas as janelas têm gelosias excepto duas que não precisam. Perante tais denúncias, a Mesa decidiu de imediato que a regente fosse advertida particularmente pelo provedor, pois "suposto nella como nas mais prelladas se nam possa presumir o perigo que se considera nas subditas terem amisades particulares", deve moderar o trato e estimação com a criada Angélica "com tal prudencia que naõ se presuma foi advertencia da mesa, mas paulatinamente va deminuindo a diferença com que a trata". Recomendava-se-lhe, também, que com as órfãs misture a severidade com a piedade e a justiça com o amor e que evite a comunicação de Joaquina Antonia e Rosa Maria, "advertindo-as particularmente com caridade e prudência" sem dar escândalo, embora, no caso de não haver emenda, as deva castigar com toda a aspereza. Finalmente, proibirá todo o ouro, salvo brincos nas orelhas que não sejam de diamantes. Na presença do escrivão, o provedor repreenderá Joaquina Antonia e Rosa Maria, a criada Angélica e a servente, que só não é expulsa porque talvez as recolhidas tenham usado de maior impertinência no modo e tempo de mandá-la. Concluindo-se que sendo a mestra incapaz, mas necessitada e sem maldade, fosse aposentada com metade do ordenado ${ }^{52}$. Decretou-se ainda que este livro se "guarde no almario novamente feito para papeis de segredo".

Na devassa de Junho de $1743^{53}$, a velha criada Silva (Maria Teresa da Silva) acusa a regente de não praticar o antigo e louvável costume de ir com as órfãs e porcionistas em comunidade dar graças ao coro depois do jantar e da ceia;

52 “... a Madre Mestra he inútil para o seu cargo e esta falta he muito essencial sem que possa disfarçarce pello grave peijuizo das recolhidas que pello tempo adiante entrarem e a cauzar inquietaçoens na comunidade devia ser expulça mas uzando de piedade com ella, por ser filha de hum Irmam e estar ha tantos anos ali recolhida com suma necessidade pella sua pobreza em atençam a ser a sua inutelidade sem dólo nem cometer delitos lhe fazem merce de a apozentar como se tem apozentado outras com doze tostoens cada mes que he a metade do ordenado e mandam que se ponham editaes para se prover o dito lugar de mestra em pessoa que seja Benemérita, e proporcionada ao emprego".

${ }^{53}$ AMC, Livro das Visitas do Recolhimento, fis. $177-188 \mathrm{v}^{\circ}$. 
de nutrir demasiada estima pela criada Angélica, causando murmuração, e de agora entrar grande concorrência de gente no recolhimento quando antigamente só se permitia a pessoas graves. Também a mestra afirma que a regente permite a entrada de quantas companheiras e mulheres as mães das órfãs trazem quando vêm visitar as filhas, o que faz "menos estimável o dito Recolhimento vadeado por semelhantes pessoas", e de mulheres que trazem cântaros de água e comestíveis porque as criadas não cumprem; mantém a antiga amizade com a criada Angélica, castiga algumas órfãs e porcionistas "dandolhe algumas pancadas com a maõ" e, além disso, guardou comestíveis na casa do comungatório, como se fosse despensa, devendo tê-la com todo o asseio. O testemunho da porteira é semelhante: deixa que entrem água e outros provimentos pela porta trazidos por mulheres de fora até ao interior do recolhimento contra o antigo costume; estranha a reiterada amizade da regente com a criada do que se seguem as ousadias desta; quando castiga as órfãs e porcionistas manda fechá-las e soltá-las pelas criadas, também contra o costume antigo e também já não se observa o que se praticava de servirem as três criadas às semanas na cozinha, ficando alguma com todo o trabalho e outras com pouco. A queixa sobre a especial amizade e parcialidade com Angélica é geral.

Acerca da porteira, regista-se apenas uma falta denunciada por várias inquiridas: é muito descansada no abrir da porta, de que se segue não esperar a gente que vem vender provimentos à portaria. Sobre as órfãs apenas se diz que duas delas usam cordões de ouro e uma outra adornos de diamante. Também várias porcionistas se apresentam ornadas com jóias semelhantes. As porcionistas, sobretudo as irmãs Teles, causam mais dissabores: tratam a regente com menos respeito e escandalizam as companheiras com as más respostas que lhes dirigem. Amestra, que se mantinha em funções, contrariando a resolução da visita anterior, revela, como seria de esperar, as mesmas incapacidades. Finalmente, a servente e duas das três criadas de dentro, são alvo de grande descontentamento. Em primeiro lugar Angélica, que suscita queixas gerais pela sua tão grande "ousadia", havendo quem se lhe refira como " $2^{\text {a }}$ Regente na autoridade"; mas também a criada Silva, que, como Angélica, se mantinha no recolhimento desde a fundação, é mal-educada e não cumpre as suas obrigações "de sorte que nem as quartas de agoa queriaõ levar as cellas" e as órfãs e porcionistas "lavam e varrem continuamente o Recolhimento". Por fim, também a servente é denunciada por ser "muito pouco atenta e cortez e pouco capaz de servir semelhante recolhimento", "molher de mas palavras", "de muito má lingoa e condição", "taõ descortez nas suas repostas que muitas se naõ querem servir delia so por lhas naõ ouvir".

Terminada a devassa nesse mesmo mês, concluíram os mesários que lendo-se o que consta da visita de 1740, se acharam agora as mesmas queixas, o que não 
é inteiramente correcto, porque, salvo o caso da regente, ninguém aludiu a amizades ilícitas. Contudo, afirmam, "atendendo a naõ constar que o disposto na Vezita passada foce legítimamente intimado a Madre Regente e mais pessoas nella comprehendidas o que se fas verosímil pello aperto do tempo em que se comcluhiu", mandam que a regente seja novamente advertida com a moderação ponderada na visita anterior; não mais admita entradas no recolhimento sem expressa licença da Mesa por escrito, sob pena de acusação de culpa grave; que não se reconheça mais por mestra a D. Josefa, mas sim por mera aposentada; que logo se prova o lugar e que a regente supra esse ministério, enquanto não for nomeada nova mestra; que as três criadas se conservem mas sejam atentas e humildes e cumpram e dividam o serviço por igual às semanas (portaria, cozinha e interior), sob pena de multa nos ordenados; que a porteira seja advertida para acudir com toda a vigilância; que sejam proibidas as peças de ouro salvo arrecadas sem pedras; e que as porcionistas Teles sejam asperamente repreendidas, sob pena de expulsão. Por fim, e como já se havia previsto na visita de 1719 , que estas determinações se escrevam em termos comedidos em livro que fique no recolhimento e que a regente fará 1er para toda a comunidade.

O livro das devassas termina em 1743. Se continuasse, o ambiente captado não seria muito diferente. Em 1748 relata-se em reunião da Mesa da Santa Casa que as porcionistas, com o pretexto de se confessarem, faziam entrar no recolhimento padres confessores particulares. Em 1753 decidiu-se em reunião da Mesa e Junta proceder à feitura de uma grade na portaria do colégio "para evitar a forçoza, e necessaria Devacidaõ que havia no recolhimento entrando nelle pessoas que alias naõ ouvera de facultarselhe a entrada havendo Logar em que pudessem falar commodamente" A grade teria uma chave que ficaria em poder da regente "a qual a não daria a orpha, ou Percionista senaõ para falar a Molheres Honestas, que focem da obrigaçaõ das mesmas Orphas, e para Homens so sendo das Percionistas Pay, Irmaõs, Thios, e das Orphas os Irmaõs, e Thios (...) e tudo percedendo Licença do Provedor". Em 1768 o provedor da Misericórdia alerta a Mesa: "a grade do cumungatorio das Orphas se profanava fazendosse Lugar de Lucutorio, e de conversasam", à qual se tinha acesso pela casa do despacho da Misericórdia, "de que rezultava murmuraçaõ e escándalo, maiormente, porque a grade do dito comungatorio era singela, e tinha postigo apto, e capaz de poder por elle entrar, e sair qualquer pessoa".

Em Agosto de 1804 a Mesa viu-se obrigada a proceder a uma reforma do recolhimento, elaborando uma "carta de providencias" "emquanto no Cazo naõ tomamos mais extensas concideraçoens, pela prompta exigencia do Cazo". Estabeleceu-se que nenhuma porcionista pudesse ser admitida ou licenciada sem autorização da Mesa e que não seria facultada a entrada a pessoa alguma 
no recolhimento, fosse de que qualidade fosse, sem despacho da mesma direcção. Ficavam proibidas de conversar com gente do exterior, exceptuando pais, irmãos ou parentas. Impunha-se o uso do mirante por grupos, proibindo que apenas uma mulher aí se instalasse, assim como também se proibia que as mais novas ocupassem as celas viradas para a rua de Coruche, remetendo-as para o lado oposto, onde existiam quintais. As cartas seriam sempre revistas pela regente. Vedava-se a todas a entrada nas celas das companheiras e se fosse necessário ocuparem duas mulheres uma mesma cela instalar-se-ia sempre uma "recolhida nova com outra de maior idade" ou então duas parentas. Proibia-se-lhes o uso de "fitas dezonestas no cabelo (...), barretinas, e outros trastes destes semelhantes". Quanto aos horários, determinava-se que se levantariam a tempo de iniciarem as orações às 5 horas no Verão e às 6 no Inverno e rezariam segunda vez no Coro, à noite, imediatamente antes do silêncio que vigorava a partir das $22 \mathrm{~h}$ no Verão e das $21 \mathrm{~h}$ no Inverno ${ }^{54}$.

Este estudo, que uma vez mais me conduz ao poder e ao uso do poder, pretende contribuir para a história da violência sobre os corpos e os espíritos. Mas ambiciona também fornecer elementos para a desconstrução de uma imagem unívoca das mulheres que tão arreigadamente permanece (o que prova a sua eficácia), embora não passe da reprodução de um modelo, da persistência de uma representação. Recordemos algumas definições básicas que nos ajudam a clarificar o pensamento.

O controlo social, que é uma forma de regular a actividade dos outros em função de valores próprios, pode ser legal ou normativo, impositivo ou difuso, usar a ordem explícita ou a manipulação, mas é sempre uma forma de violência, que mais não é do que o exercício da coacção. Outras formas serão a indução de sofrimento moral e/ou físico através da dor, da prisão, da segregação, da humilhação. O controlo social é absoluto se se conseguir que os outros incorporem e façam seus os valores alheios. O controlo, então, é exercido pelo próprio controlado sem que ele tenha disso consciência. Trata-se da célebre alienação denunciada por Marx ou a total sujeição ao super-ego na definição de Freud. A existência dos recolhimentos e a das devassas eram a materialização da lógica que presidia às relações entre homens e mulheres, a lógica da violência, que começava com a segregação espacial, confinando-se os corpos, e ia até à construção do pensamento, valores e emoções. As mulheres tinham de ser treinadas na aplicação de técnicas de disciplina de si ${ }^{55}$, na canalização das emoções, no controlo das vontades,

54 Maria Antónia Lopes, Pobreza, assistência e controlo social..., I, pp. 500-504.

55 Cécile Dauphin, "Fragiles et puissantes, les femmes dans la société du XIXe siècle" em Cécile Dauphin e Arlette Farge, (dir.), De la violence et des femmes, Paris, Albin Michel, 1999, pp. 104-109. 
do diálogo intemo, do autoconceito, da auto-estima - um trabalho imenso de domínio para conduzir ao tal auto-controlo. Como diria Foucault, eram almas cujas representações se manipulavam ${ }^{56}$. Mas como afirma ainda o mesmo autor - embora me pareça que com frequência o esqueceu -, uma sociedade disciplinar não é sinónimo de sociedade disciplinada ${ }^{57}$. Há sempre pluralidade de comportamentos e pluralidade de inadequação entre os quadros normativos e as acções ${ }^{58}$. $\mathrm{O}$ ambiente do recolhimento revelado pelas devassas demonstra-o à saciedade. Deve ser, pois, salientada a distinção entre os arquétipos e a vida no seu quotidiano, as atitudes espontâneas e os sentimentos, que o historiador, muito mais penosamente, vai captando. E o quotidiano do recolhimento é violento, conflituoso. Há intrigas, difamações, constituição de facções inimigas, lutas pelo poder, violência verbal, violência física: bofetadas, arranhões, porte de navalha e ameaça de a usar. É evidente a frustração que desemboca em agressividade e em compensações diversas. E há também omissões esclarecedoras não só do ambiente do recolhimento como do desinteresse dos inquiridores sobre certos comportamentos desviantes: o roubo só uma vez é aludido e a embriaguez está ausente; nunca são denunciadas leituras perigosas de carácter religioso ou amatorio; são também inexistentes os casos de heresia, blasfémia, superstição ou prática de encantamento.

Os dirigentes da Misericórdia não conseguiram que as mulheres recolhidas interiorizassem as suas normas, revelando-se incapazes de as controlar, de as corrigir, de as obrigar a prezar e a viver segundo o modelo da mulher perfeita: em silêncio e isolamento, com modéstia e sisudeza, numa reverente submissão aos superiores. São muitas as recolhidas de Coimbra, incluindo as serventes, que, claramente voluntaristas, falam alto, gritam, cantam, jogam, insultam-se, rogam pragas, batem-se, desrespeitam as autoridades, comunicam com o exterior, adomam-se, polvilham-se, apaixonam-se, tocam-se. Não deveria ser difícil o domínio das consciências destas mulheres, tanto mais fácil quanto eram pobres, mal apetrechadas culturalmente, desde sempre treinadas na submissão ${ }^{59}$, morando no recolhimento por esmola, sujeitas a expulsão e sem alternativas de vida.

56 Surveiller et punir..p. 155.

57 Cit. por Jacques-Guy Petit, "Le philanthrope et la cité panoptique" em Luce Giard (dir.), Michel Foucault. Lire l'œuvre, Grenoble, Jérôme Millon, 1992, p. 180.

58 Com esta mesma conclusão encerra Margarida Neto a sua síntese "O papel da mulher na sociedade portuguesa setecentista. Contributo para o seu estudo" em Júnia Furtado, Diálogos Oceánicos. Minas Gerais e as novas abordagens para urna historia do Império Ultramarino Português, Belo Horizonte, UFMG, 2001, pp. 25-44.

59 E, em principio, grande parte delas na contenção de modos. Lembremo-nos que estamos perante uma certa pobreza envergonhada, recebendo muitas destas mulheres o tratamento de "Dona". 
E, contudo, é bem visível que os homens da Santa Casa não lograram ganhar-lhes nem o respeito, a gratidão e a reverência que, segundo as suas concepções, lhes eram devidos, nem sequer a obediência formal dos gestos e modos.

Aclimatadas algumas, decerto ilustradas quase todas, pôis não seria esse o seu projecto de vida, e longe ainda de possuírem uma "consciência de género", muitas souberam, apesar de tudo, criar, num protesto implícito, o seu pequeno espaço de liberdade e autonomia por entre as falhas do sistema que as dominava. Que era imperfeito, não restam dúvidas, ou não seria possível que, dispondo de recursos tão desiguais, elas tivessem conseguido tais níveis de rebeldia, patentes ao longo de toda a história conhecida da instituição. E a grande fragilidade do sistema mais não era do que a ficção do estereótipo feminino que não reflectia a realidade, que só a mascarava, mas que ninguém estava disposto a admitir ou tinha, sequer, capacidade para o fazer. Pelo contrário, um tão grande fosso entre a representação e o real só poderia ser interpretado como incompetência dos órgãos dirigentes. Assim, se os desvios fossem conhecidos, se tal fracasso fosse do domínio da opinião pública, ruiria o capital simbólico da Misericórdia Totalmente condicionados pela imagem pré-concebida das mulheres, os mesários estavam manietados pelo medo do escândalo. E foi essa a arma utilizada pelas recolhidas. 


\section{Anexos}

\begin{tabular}{|c|c|c|c|c|c|}
\hline Delitos da regente & Denúncias & $\%$ & Delitos da porteira & Denúncias & $\%$ \\
\hline Frouxidão & 68 & 42 & Incumprimento de deveres de ofício & 128 & 49 \\
\hline Parcialidade & 29 & 18 & Parcialidade e fomento de inimizades & 62 & 24 \\
\hline Rigor em demasia ou aspereza & 28 & 17 & Grosseria ou aspereza & 29 & 11 \\
\hline Amizade escandalosa & 19 & 12 & Divulgação no exterior de conflitos internos & 7 & 3 \\
\hline Incumprimento de deveres de ofício & 16 & 10 & Frouxidão & 2 & 1 \\
\hline Correspondência ilícita com o exterior & 1 & 0 & Correspondência ilícita com o exterior & 1 & 0 \\
\hline Total & 161 & 100 & Total & 260 & 100 \\
\hline
\end{tabular}

\begin{tabular}{|l|r|r|l|c|c|}
\hline \multicolumn{1}{|c|}{ Delitos da mestra } & Denúncias & $\%$ & \multicolumn{1}{c|}{ Delitos das criadas } & Denúncias & $\%$ \\
\hline Ignorância & $\mathbf{2 8}$ & $\mathbf{5 1}$ & Desrespeito & $\mathbf{1 0 2}$ & $\mathbf{5 2}$ \\
\hline Parcialidade e fomento de inimizades & $\mathbf{1 0}$ & $\mathbf{1 8}$ & Incumprimento de obrigações & $\mathbf{4 6}$ & $\mathbf{2 3}$ \\
\hline Analfabetismo & $\mathbf{6}$ & $\mathbf{1 1}$ & Grosseria ou aspereza & $\mathbf{3 0}$ & $\mathbf{1 5}$ \\
\hline Aspereza & $\mathbf{5}$ & $\mathbf{9}$ & Uso de roupas e/ou adereços proibidos & $\mathbf{8}$ & $\mathbf{4}$ \\
\hline Falta de jú́zo & $\mathbf{3}$ & $\mathbf{5}$ & Comunicação ilícita com o exterior & $\mathbf{5}$ & $\mathbf{3}$ \\
\hline Incapacidade pedagógica & $\mathbf{3}$ & $\mathbf{5}$ & Amizade escandalosa & $\mathbf{5}$ & $\mathbf{3}$ \\
\hline & & & Conivência na comunicação com o exterior & $\mathbf{2}$ & 1 \\
\hline Total & $\mathbf{5 5}$ & $\mathbf{1 0 0}$ & Total & $\mathbf{1 9 8}$ & $\mathbf{1 0 0}$ \\
\hline
\end{tabular}

\begin{tabular}{|l|c|c|l|c|c|}
\hline \multicolumn{1}{|c|}{ Delitos das órfãs } & Denúncias & $\%$ & \multicolumn{1}{|c|}{ Delitos das porcionistas } & Denúncias & $\%$ \\
\hline Comportamento impróprio & $\mathbf{6 7}$ & $\mathbf{2 3}$ & Comunicação ilícita com o exterior & $\mathbf{8 2}$ & $\mathbf{1 8}$ \\
\hline Inimizades que mantém e/ou fomenta & $\mathbf{5 6}$ & $\mathbf{1 9}$ & Inimizades que mantém e/ou fomenta & $\mathbf{8 0}$ & 17 \\
\hline Amizade escandalosa & $\mathbf{5 3}$ & $\mathbf{1 8}$ & Comportamento impróprio & $\mathbf{7 8}$ & 17 \\
\hline Comunicação ilícita com o exterior & $\mathbf{4 7}$ & $\mathbf{1 6}$ & Desrespeito às preladas & $\mathbf{6 7}$ & 14 \\
\hline Desrespeito às preladas & 24 & $\mathbf{8}$ & Grosseria ou aspereza & $\mathbf{5 1}$ & H \\
\hline Uso de roupas ou adereços proibidos & $\mathbf{2 2}$ & $\mathbf{8}$ & Amizade escandalosa & $\mathbf{4 3}$ & $\mathbf{9}$ \\
\hline Grosseria ou aspereza & 21 & $\mathbf{7}$ & Uso de roupas ou adereços proibidos & $\mathbf{3 7}$ & $\mathbf{8}$ \\
\hline Faltas às orações ou outras obrigações & $\mathbf{1}$ & $\mathbf{0}$ & Faltas às orações ou outras obrigações & $\mathbf{1 9}$ & 4 \\
\hline & & & Desrespeito à Mesa & $\mathbf{8}$ & $\mathbf{2}$ \\
\hline Total & $\mathbf{2 9 1}$ & $\mathbf{1 0 0}$ & Total & $\mathbf{4 6 5}$ & $\mathbf{1 0 0}$ \\
\hline
\end{tabular}

